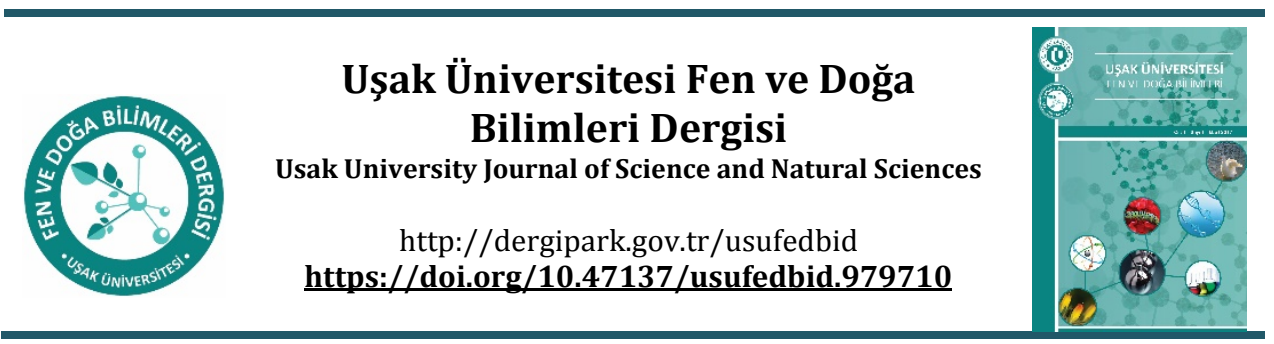

Derleme Makalesi

\title{
Biyolojik Mücadelede Trichoderma'lar ve Biyolojik Kontrol Mekanizmaları
}

\author{
Deniz BULUT, Havva DINLER* \\ *Bitki Koruma Bölümü, Ziraat Fakültesi, Ușak Üniversitesi, Ușak, Türkiye

\begin{abstract}
Pesticides have been widely preferred in chemical control for many years in the management against plant diseases in agricultural production. Intensive and uncontrolled use of pesticides, deterioration of the natural balance, negative effects on the environment and human health, as well as residue problems of chemicals cause serious problems in marketing. Due to the prohibition of most chemical fungicides by the European Union, it has brought along the search for new methods in the control of plant diseases as a sustainable alternative. The first method that comes to mind in the management against plant diseases, which can be sustainable, environmentally friendly and effective for a long time, is biological control. In recent years, many studies have been conducted on biological agents. Trichoderma species from these biocontrol factors are used as biocontrol agents in the control of plant pathogenic fungi. At the present time, commercial products of Trichoderma are used as biopesticide, soil conditioner and plant growth regulator. In this review, the importance of Trichoderma in biological control, the mechanisms of action of Trichoderma species and their use in biotic and abiotic stress conditions were examined.
\end{abstract}

Keywords: Biological control, plant pathogens, antagonist microorganism, Trichoderma spp..

\section{Özet}

Tarımsal üretimde bitki hastalıklarıyla mücadelede pestisitler uzun yıllardan bu yana kimyasal mücadelede yaygın olarak tercih edilmektedir. Pestisitlerin yoğun ve kontrolsüz bir şekilde kullanımı doğal dengenin bozulması, çevre ve insan sağlığına olumsuz etkileri ayrıca kimyasalların kalıntı sorunları da pazarlamada ciddi sıkıntılara sebep olmaktadır. Çoğu kimyasal fungisitlerin Avrupa Birliği tarafından yasaklanması nedeniyle sürdürülebilir bir alternatif olarak bitki hastalıklarının mücadelesinde yeni yöntem arayışlarını beraberinde getirmiştir. Bitki hastalıklarıyla mücadelede sürdürülebilir, çevre dostu ve uzun süre etkili olabilecek ilk akla gelen yöntem biyolojik mücadele olmaktadır. Son yıllarda biyolojik ajanlara yönelik yapılan çalışmalar hız kazanmaktadır. Bu biyokontrol etmenlerinden Trichoderma'lar bitki patojeni fungusların mücadelesinde uzun süredir çok yönlü biyokontrol ajanı olarak yer almakta ve günümüzde Trichoderma'ların ticari ürünleri; biyopestisit, toprak düzenleyici ve bitki gelişim düzenleyici olarak da kullanılmaktadır. Bu derlemede biyolojik mücadelede Trichoderma'nın önemi, Trichoderma türlerinin etki mekanizmaları ile biyotik ve abiyotik stres koşullarında kullanımları konusunda yapılan çalışmalara yer verilmiștir.

Anahtar Kelimeler: Biyolojik mücadele, bitki hastalıkları, antagonist mikroorganizmalar, Trichoderma spp.,

(C)2021 Usak University all rights reserved.

*Corresponding author:

E-mail: havva.dinler@usak.edu.tr (ORCID ID: 0000-0002-7011-5183)

(C)2021 Usak University all rights reserved. 


\section{Giriş}

Tarımsal üretim, dünya genelinde insanların geçim kaynağı olmasının yanı sıra insan ve hayvan beslenmesinde ve endüstri alanlarında ana hammadde kaynağ almaktadır. İklim değişikliklerinden ve yeni ortaya çıkan hastalık ve zararlı türlerinden dolayı, 2050 yılına kadar dünya genelinde yaklaşık 9,8 milyar insanın besin ihtiyacını karşılamak için tarımsal ürünlerin veriminin \% 70 oranında arttırılması gerekmektedir [1]. Çeşitli ülkelerde yetişticiliği yapılan kültür bitkilerinde bitki patojeni fungus, bakteri, virüs, nematodlar, böcekler, yabancı otların neden olduğu biyotik faktörlerden dolayı \% 31-42 oranında verim kayıpları belirtilirken, bununla birlikte ekstrem hava koşulları, tuzluluk, alkalilik, asitlik, toprak kirleticiler, kuraklık, sel vb. abiyotik faktörler de toprak sağlığının bozulmasına neden olmaktadır. Tarımsal üretimin iyileștirilmesi ve arttırılmasının başlıca yollarından biri de bu stres kaynaklı kayıpların azaltılmasıdır.

Tarımsal üretimde bitki hastalıklarıyla mücadelede kimyasal mücadele uzun yıllardır yaygın olarak tercihedilen yöntemlerdendir. Pestisitlerin yoğun ve kontrolsüz bir şekilde kullanımı doğal dengenin bozulması, çevre ve insan sağlı̆ına olumsuz etkileri ve ayrıca kimyasal fungisitlerin çoğunun Avrupa Birliği tarafından yasaklanması nedeniyle bitki hastalıklarının mücadelesinde sürdürülebilir, alternatif yeni yöntem arayışlarını da beraberinde getirmiştir [2]. Dolayısıyla tüm bu olumsuz etkileri nedeniyle son yıllarda hastalıklarla mücadelede kimyasalların kullanımını azaltmak amacıyla yeni alternatif yöntemler oldukça gerekli hale gelmiştir. Günümüzde dikimden önce toprağa uygulanan kimyasallar, uygun uygulama yöntemleriyle birlikte etkili araçlar ile kullanılırsa topraktaki inokulum miktarının önemli ölçüde azaltılabileceği bildirilmiştir [2].

Bitki dikimi yapılmadan önce buhar uygulaması, solarizasyon ve anaerobik toprak dezenfesiyonu gibi kimyasal olmayan uygulamalar, toprakta inokulum miktarının azalmasına neden olmakta, ancak kullanılan bu yöntemlerin etkileri sınırlı kalmaktadır $[3,4]$. Bu amaçla bitki hastalıklarıyla mücadele sürdürülebilir, çevre dostu ve uzun süre etkili olabilecek ilk akla gelen yöntemlerden biri biyolojik mücadele olmaktadır. Biyolojik mücadele bitki hastalıklarıyla savaşımda bu gereksinimleri karşılayan ve tarımda yaygın olarak kullanılan bir alternatif mücadele yöntemi olarak görülmektedir [5,6-7].

Son yıllarda biyolojik ajanlara yönelik çalışmalar hız kazanmakta ve yöntemin tercih edilmesinde ki öncelik pestisit kullanımının azaltılarak veya daha az miktarlarda kullanılmalarının sağlanmasıdır [8,9]. Günümüzde biyolojik kontrol etmenlerinden Aspergillus, Gliocladium, Trichoderma, Ampelomyces, Candida, Coniothyrium, Bacillus, Pseudomonas ve Agrobacterium genusları bitki hastalıklarıyla biyolojik mücadelede yaygın olarak kullanılmaktadır [10,11,12,13, 14,3-4].

Bu biyokontrol etmenlerinden Trichoderma'lar bitki patojeni fungusların mücadelesinde uzun süredir çok yönlü biyokontrol ajanı olarak yer almıştır. Trichoderma türlerinin izole edilmesi oldukça kolay olup, fungus organik maddeler üzerinde hızla büyümekte ve çeșitli bitkilerin köklerinden, çürümüş kabuk dokularından, sklerotlardan veya fungusların diğer üreme organlarının üzerinden izole edilebilmektedir [10-15]. Trichoderma türlerinin bitki hastalıkları ile mücadelede uzun süredir kullanılan çok yönlü etkili biyokontrol etmenleri olduğu çok sayıda çalıșmada belirtilmiș [16] ve günümüzde Trichoderma'ların ticari ürünleri, biyopestisitler, toprak düzenleyicileri ve bitki gelișim düzenleyicileri olarak kullanılmaktadır [10,17,18-19]. Son yıllarda toprak kaynaklı patojenlerle mücadelede etkili, ekonomik ve ticari olarak üretimi yapılan biyokontrol ürünleri arayıșı ortaya çıkmıștır. Bitki hastalıklarıyla mücadelede günümüzde bazı biyolojik kontrol ajanları, hali hazırda preparat haline getirilerek tarla koşullarında 
kullanılmaları amacıyla ticari olarak formülasyon haline getirilmektedir [20]. Bu antagonistlerin mikoparazitizm, yer-besin için rekabet, antibiyotik ve sekonder metabolit üretimi, bitki savunmasını uyarma şeklinde farklı etki mekanizmaları mevcut olup [21,22,8-9] bitki gelişimi ve ürün verimini de arttırmaktadırlar [23].

Bitki patojenleri kullanılan kimyasal pestisitlerden dolayı direnç kazanmakta ve patojenler fungisitlere dirençli hale gelmektedirler. Bu nedenle çoğu zaman bitki hastalıkları ile mücadele etmek, kontrol altına almak oldukça güç olmaktadır. Kimyasal pestisitlerin uygunsuz kullanımından dolayı, üretim maliyetlerinin artması ve gelirin azalması nedeniyle üreticiler, biyokontrol etmenlerinin önemli etkilerinden dolayı, ekonomik, çevre dostu, biyotik ve abiyotik stres koşullarını yöneten, sürdürülebilir, etkili entegre mücadele arayıșındadırlar [24]. Günümüzde, Trichoderma spp., sürdürülebilir hastalık mücadele (yönetim) programlarında bitki hastalıklarını kontrol etmek amacıyla kullanılmaktadır-Etkili ve verimli șekilde kullanılması için ajanların etki mekanizmalarının nasıl ișlediği ve bu mekanizmaların etkisini azaltan ve sınırlandıran faktörlerin neler olduğunun bilinmesi gerekmektedir. Böylelikle, biyokontrol ajanlarının uygulanması ve kullanımı konusunda etkili yöntemler geliștirilebilir. Bu derlemede biyolojik mücadelede Trichoderma'nın önemi, Trichoderma türlerinin etki mekanizmaları ile biyotik ve abiyotik stres koşullarında kullanımları konusunda yapılan çalıșmalar incelenmiştir.

\section{Trichoderma spp. ile İlgili Genel Bilgiler}

Trichoderma'lar, ilk olarak Almanya'da 1794 yllında Persoon tarafından teşhis edilmiş ve daha sonra birçok araştırıcı tarafından Trichoderma türleri üzerinde yoğun çalışmalar yapılmıștır. Weindling [25], Trichoderma lingnorum'un (viride), toprak kökenli fungal patojen olan Rhizoctonia solani'ye ve daha sonraları aynı Trichoderma türünün Phytophthora, Pythium, Rhizopus ve Sclerotium rolfsii'ye mikoparazitik etki gösterdiği bulunmuştur [26]. Trichoderma türlerinin mikoparazit özellikleri ve üretmiş oldukları antibiyotikler ile ilk olarak 1934'lü yıllarda antifungal etkilerinin belirlenmesi [27] konunun önemi iyice artmış ve günümüze kadar birçok çalışma yapılmıştır. Trichoderma'ların bitki hastalıklarıyla mücadelede özellikle de toprak kaynaklı patojenlere karşı etkilerinin yanında aynı zamanda toprakta bitki kalıntılarını ayrıştırmak, rizosfer kolonizasyonunu, bitkiler tarafından makro ve mikro besin elementlerinin alınımını arttırarak bitki büyümesini, kök gelişimini teșvik etmek ve bitki savunma mekanizmalarını arttırmak gibi çeșitli özellikleri de bulunmaktadır [19,18-24].

Trichoderma türleri dünya genelinde geniş bir yayılım gösteren hemen hemen her türlü toprakta, çürümüş bitki parçalarında ve diğer substratlarda yoğun olarak bulunabilen, anaerobik, fakültatif ve kozmopolit funguslardır [28,29]. Trichodermalar (teleomorph: Hypocrea); funguslar alemi, Ascomycota şubesi; Pezizomycotina alt şubesi; Euascomycetes veya Sordariomycetes sınıfi; Hypocreales takımı; Hypocreaceae familyasında yer almakta ve 200 'den fazla türü kapsamaktadır [24]. Trichoderma türleri biyotik ve abiyotik stres yönetimi, bitki büyümesini teşvik edici enzimler ve antibiyotik üretimi/endüstriyel kullanımlar, moleküler biyoloji, transgenik ürünler ve ticari biyofungisitler vb. gibi alanlarda kapsamlı bir şekilde çalışılmakta ve kullanılmaktadır. Organik maddenin polisakkaritlerinin ayrışmasında önemli bir rol oynarlar ve bitki kök ekosistemlerinin rizosferinde ve kök yüzeyinde bulunabilirler [30,31]. T. harzianum, $T$. viride, T. virens, T. asperellum vb. 200'den fazla Trichoderma türü dünyanın her yerinde farklı ekosistemlerde rapor edilmiștir [32,33-34]. Kozmopolittirler, tarım topraklarında, çöl topraklarında, meralarda, bataklık arazilerde, göllerde, çeşitli ekosistemlerde tuzlu 
topraklarda her yerde bulunabilirler [18]. Ancak T. agresivum, T. pleurotophilum ve T. fulvidum; Agaricus bisporus (kültür mantarı) ve Pleurotus ostreatus (kavak mantarı)'da yeșil küf hastalığına neden olmaktadırlar. Bu Trichoderma türleri, yer ve besin maddesi için etkin bir șekilde rekabet ederek, hücre dișı enzimler, toksik sekonder metabolitler, uçucu organik bileșikler üreterek mantarın büyümesini engeller ve ürünlerde önemli verim kayıplarına neden olabilirler [35,36-37]. Bu nedenle, P. ostreatus'da (kavak mantarı) yeșil küfe neden olan T. pleurotum ve T. pleuroticola'nın hızlı bir șekilde tanılanmasında, patojenlerin PCR analizi ile teșhiș yöntemleri geliștirilmiștir [38]. Benzer șekilde, T. longibrachiatum'un bağıșıklığı düșük insanlarda ortaya çıkan fungal patojen olduğu rapor edilmiștir [22,39]. Endofit olarak yașayan Trichoderma türleri yaprak, kök, odun parçaları, tek yıllık ve odunsu bitkilerin birçok dokusunda tespit edilmis fungal patojenleri baskı altına alarak konukçuya birçok avantaj sağlamaktadır [40,41,42-43]. Bitki konukçusu için oldukça faydalı biyoaktif sekonder metabolitleri salgılarlar. Gen aktivasyon modelini değiștirerek mikrobiyal etkileşimleri ve bitki fizyolojisini etkilerler [44]. Azotlu gübrelerin daha yüksek alınmasını sağlayan fitohormonların üretimine yardımcı olur, otçulları ve patojenleri engelleyen biyoaktif ikincil toksik metabolitlerin üretimi, hastalıklara karşı direnci arttırır ve bitkilerin kuraklığa alışmasına yardımcı olur, ağır metal toleransı, düşük $\mathrm{pH}$, yüksek tuzluluk, daha fazla fotosentetik ürün üretimini sağlarlar [45,46]. Hindistan'da Pusa Basmati-1 çeltik çeşidinde T. asperellum ve $T$. asperelloides [47]; Çin'de Dendrobium nobile (orkide) de T. chlorosporum [48]; Theobroma cacao (kakao)'da Brezilya'da T. martiale [49], ABD [50] T. hamatum ve Endonezya'da T.asperellum [51]; Amazon havzasinda Hevea spp.'den T. amazonicum[30]; olmak üzere yapılan çalışmalarda farklı ülkelerde birçok endofit tür tespit edilmiştir.

Bununla birlikte mercimekte T. gamsii [52] ve Himalaya izolatı T. gamsii, Phoma herbarum, Fusarium flocciferum'nin mücadelesinde umut verici biyokontrol ajanları olduğu kabul edilmiştir [53]. Endofitik Trichoderma türleri Pinus halepensis'in (halep çamı) fidelerinde Gremmeniella abietina'nin meydana getirdiği nekroz belirtilerinin azalmasına neden olmuştur [54]. Bu tür endofitik Trichoderma türlerinin hastalık ve zararlılarla mücadelede bitki koruma yöntemleri içinde kullanılması bitkisel üretimde tarımsal girdileri en aza indirmek açısından oldukça önemlidir [30,55-56].

\section{Trichoderma spp.'nin Biyolojik Kontrol Mekanizmaları}

Trichoderma türlerinin biyolojik kontrol mekanizmaları onlarca yıldır incelenmektedir $[18,57]$. Bu non-patojen olan toprak kaynaklı mikroorganizmalar, fungal patojenlere karșı antagonist ve mikoparazit etkilere, bitki kök sisteminin ve bitki savunma mekanizmalarını uyarma yeteneğine sahiptirler [58]. Fitohormon aracılığıyla ortaya çıkan savunma mekanizmaları, sistemik kazanılmıș dayanıklılık (SAR) ve uyarılmıș sistemik dayanıklılık (ISR) olarak bilinir [59]. Bitkilere faydalı funguslar olan Trichoderma türleri, jasmonatlara (JA) ve etilene (ET) bağlı olmalarından dolayı, ISR mekanizmalarını uyarma yetenekleri ile bilinmektedir [58]. Bazı Trichoderma türlerinin salisilik asit (SA) aracılığıyla bitki savunmasını uyardığı da bildirilmiştir [60,61].

Antagonistik mikroorganizmalar, toprak kökenli patojenlerin gelișimini doğrudan veya dolaylı olarak kontrol edebilirler. Bitki hastalıklarına karşı etkili biyokontrol ajanı olan Trichoderma türleri yer ve besin için rekabet ederek, çevre koșullarını değiștirerek veya bitki büyümesini ve bitki savunma mekanizmalarını, antibiyosisi teşvik ederek veya doğrudan mikoparazitizm gibi mekanizmalarla dolaylı olarak etki hareket edebilirler [10,8-19]. Antagonist Trichoderma spp.'nin patojen funguslara karşı etki mekanizması, yer ve besin için rekabet, patojenin sporlarının çimlenmesini engelleyen metabolit üretimi ve patojenin doğrudan temas yoluyla toksik olarak ve antibiyosis ile hücreleri 
öldüren hidrolitik enzimlerin sentezi gibi interaksiyonu çeşitli şekillerde gerçekleşmektedir [9]. Biyolojik mekanizmalar, yer ve besin için rekabet; antibiyosis; mikoparazitizm; konukçu bitkinin savunma mekanizmasının uyarılması; vb. bitki hastalıklarının kimyasal mücadelesine alternatif olarak biyotik stres/hastalıkların kontrol altına alınmasına yardımcı olmaktadır [17;Tablo 1].

Tablo 1. Trichoderma spp.'nin bitki patojenlerine karşı biyolojik kontrol mekanizmaları

\begin{tabular}{|c|c|c|}
\hline $\begin{array}{l}\text { Mekanizma } \\
\text { șekli }\end{array}$ & Mekanizma & Görevi \\
\hline \multirow{2}{*}{$\begin{array}{l}\text { Dolaylı } \\
\text { (indirect) } \\
\text { olarak } \\
\text { antagonizm }\end{array}$} & $\begin{array}{l}\text { Yer, besin-beslenme için } \\
\text { rekabet }\end{array}$ & $\begin{array}{l}\text { Kökleri çok hızlı bir şekilde kolonize } \\
\text { eder ve besin maddelerini kullanır. } \\
\text { Fiziksel olarak alan işgal eder. }\end{array}$ \\
\hline & $\begin{array}{l}\text { Konukçu dayanıklılığının } \\
\text { uyarılması }\end{array}$ & $\begin{array}{l}\text { Bitki ile işbirliği, bitki hormonları } \\
\text { salisilik asit, jasmonik asit ve etilenin } \\
\text { aracılık ettiği bir sinyal ağı aracılığıyla } \\
\text { moleküler tanımayı sağlar. } \\
\text { İlgili metabolitlerin ve fenilalanin } \\
\text { amonyak liyaz (PAL), kitinaz, glukanaz, } \\
\text { vb. enzimlerin üretimi aracılığılla bitki } \\
\text { savunma reaksiyonunda bir dizi } \\
\text { biyokimyasal değișiklik bașlatır. }\end{array}$ \\
\hline $\begin{array}{l}\text { Doğrudan } \\
\text { (direct) } \\
\text { antagonism }\end{array}$ & $\begin{array}{l}\text { Hyperparazitizm/baskı } \\
\text { altına alıp engellemek }\end{array}$ & $\begin{array}{l}\text { Hücre duvarını parçalayan kitinaz, } \beta-1 \text {, } \\
3 \text { glukanaz, glikozit hidrolazlar, } \\
\text { proteazlar vb. enzimler fungal bitki } \\
\text { patojenlerinin hücre duvarının } \\
\text { parçalanmasına ve ölümüne neden } \\
\text { olur. }\end{array}$ \\
\hline $\begin{array}{l}\text { Birleşik } \\
\text { (mixed) } \\
\text { antagonizim }\end{array}$ & Antibiozis/Liziz & $\begin{array}{l}\text { Düşük moleküler ağırlıklı sekonder } \\
\text { metabolitlerin aracılık ettiği biyoajanlar } \\
\text { ve bitki patojenleri arasındaki } \\
\text { antagonistik etkileşim veya } \\
\text { patojenlerin büyüme ve gelişimini } \\
\text { etkileyen biyoajanların antibiyotikleri, } \\
\text { örn. gliovirin, gliotoksin, pironlar ve } \\
\text { peptaiboller, vb. }\end{array}$ \\
\hline
\end{tabular}

\section{Yer ve besin için rekabet}

Trichoderma türleri dünyada geniș bir yayılıș alanına sahip, hemen hemen her türlü habitatlarda gelişen oldukça hızlı büyüyen funguslardır ve diğer funguslar gibi heterotrofiktir ve toprak kökenli patojenlerle; Fusarium, Pythium, Rhizoctonia, Sclerotium gibi diğer mikroorganizmalar ile yer ve besin maddesi için karbon, nitrojen, fosfor, demir, mineraller vb. için rekabet ederler [62]. Yer ve besin için patojenlere karşı çok etkili rakip olan [63] Trichoderma spp., herbisitler, fungisitler ve fenolik bileşikler dahil olmak üzere birçok toksik bileşiğe doğal olarak dayanıklıdırlar. $\mathrm{Bu}$ nedenle, spor çimlenmesini engelleyen (fungustatik), hücreleri öldüren (antibiyosis) veya rizosferi değiștiren (örneğin, patojenlerin gelişmemesi için toprağı asitleştirerek) metabolik bileşikler üreterek hızla gelişir ve patojenlerin gelişimini engellerler [9]. Açlık, mikroorganizmalar 
için en yaygın ölüm nedeni olup, az miktarda olan sınırlı besin için rekabet, özellikle bitki hastalıklarının biyolojik kontrolünde oldukça önemlidir. Demir alımı, ipliksi (filamentous) funguslar için gereklidir ve demir eksikliğinde funguslar, sideroforlar olarak adlandırılan düșük moleküler ağırlıklı ferrik demire özgü șelatörler salğılayabilir ve demiri șelatlayan ve diğer fungusların büyümesini durduran yüksek verimli sideroforlar üretebilirler [9]. Bu nedenle, toprak özellikleri biyolojik kontrol ajanı olarak Trichoderma'yı etkilemektedir.

\section{Antibiyosis ve lizis}

Antibiyosis; Düşük moleküler ağırlıklı metabolik bileşikler veya bunlar tarafından salgılanan antibiyotikler nedeniyle bir organizmanın diğeri tarafından büyüme ve gelişminin engellenmesidir. Trichoderma türleri, gliovirin, a-piron, peptaiboller, trikotoksinler, asperelinler, trikopolinler, alametisinler, 6-pentil- $\alpha$-piron, massoilakton, heptelidik asit [64]; gibi uçucu ve uçucu olmayan toksik metabolitler salgılarlar, patojenlerle interaksiyonlarında antagonistik sinyal molekülleri olarak hareket eder, büyümelerini etkileyerek [18,9] patojen kolonizasyonunu engellerler [65]. Mikroorganizma tarafından salgllanan hidrolitik enzimler ve antibiyotikler, antagonizm seviyesini arttırmaktadır. Botrytis cinerea ve Rhizoctonia solani' ye karşı T.harzianum'dan elde edilen endokitinaz enzimi ile gliotoksin hidrolitik enzimler ve peptaibol hücre dışı enzimleri ve $\alpha$-piron arasında oldukça yüksek düzeyde bir sinerjistik antagonizm gözlendiği belirtilmiștir $[66,8]$. B. cinerea propagüllerine antibiyotik kombinasyonları ve birkaç çeşit hidrolitik enzim uygulandığında ve $F$. oxysporum'da sinerjizm oluşmuş, ancak antibiyotiklerden sonra enzimler eklendiğinde ise sinerjizm daha düşük bulunmuş, bu da sinerjistik etkileşimi oluşturmak için hücre duvarı bozulmasının gerekli olduğunu göstermiştir [8].

Lizis; Bitki ve hayvan hücrelerinin hidrolitik enzimler tarafından parçalanmasıdır. Trichoderma'lar kitini, proteinleri, selülozu, DNA'yı vb. çözen hücre duvarı liziz enzimi yani kitinaz, glukanaz vb. polimerik bileşikler salgılarlar[67].

\section{Mikoparazitizm}

Trichoderma ve patojen arasındaki doğrudan etkileşime mikoparazitizm denir. İlk defa 1932 yılında Weindling Trichoderma türlerinin biyokontrol ajanı olduğunu ve ayrıca $T$. lignorum (viride) hiflerinin R. solani'yi parazitleyerek öldürmesini mikoparazitizm olarak ifade etmiștir [26]. Mikoparazitizm, hücre duvarının litik enzim üretimini içeren karıșık mekanizmadır [18]. Trichoderma spp.'nin litik enzimleri, fungal patojenlerinin hücre duvarlarının sindiriminde rol aldı ̆̆ı [68,69], patojen kontrolünde aktif olarak bulunduğu bilinmektedir [70]. Kitin ve $\beta$-1,3-glukanlar, fungus hücre duvarlarının ana yapısal bileșenleridir [71,72-73]. Trichoderma spp. bir çok fungusu parazitleyerek, diğer fungusları da tespit ederek ve onlara doğru miselyum geliştirerek doğrudan biyokontrol sağlar. Belirli mesafeden algılama ise, çoğunlukla kitinaz, glukanaz ve proteazlar olmak üzere hücre duvarını parçalayan enzimlerin ekspresyonundan kaynaklanmaktadır [18]. Her enzimin yapısı bir Trichoderma türünden diğerine farklılık gösterir. Fungusların ekzokitinazları yapısal olarak düşük seviyelerde salgıladığı düşünülmektedir. Kitinazlar fungusun hücre duvarlarını bozduğunda, ekzokitinazları uyaran oligomerleri serbest bırakırlar ve saldırı başlar. Chet ve ark. [74] mikoparazitizmin, kemotropizm ve tanıma; tutunma ve sarma; hücre duvarı penetrasyonu; ve konukçu hücrenin sindirimi olarak dört aşamada gerçekleştiğini ifade etmektedir. Sırayla birinci aşamada mikoparazit konukçuya yönelerek kemotrofik gelişir, daha sonra ikinci aşamada diğer konukçu olan bitki patojeni fungusları tanır, onlara doğru gelişir, üçüncü aşamada hücre duvarını parçalayan hidrolitik enzimler salgılar ve dördüncü olan son aşamada da konukçu olan 
patojenin hiflerine bağlanarak, hiflerini sarar. Ardından konukçu yüzeyinde bir appressorium oluşturarak, konukçu hücreye nüfuz ederek konukçu hifleri parazitlemektedir [75]. Mikoparazitizmin moleküler düzeyde uyarılması ilk olarak 1994'te [76], endokitinaz kodlayan bir genin (ech42) düzenlenmesine dayalı olarak ortaya konmuştur. Ech42, T. harzianum ve $R$. solani arasındaki mikoparazitik interaksiyon sırasında belirlenmiștir. Ayrıca bașka bir çalıșmada, T. atroviride'nin P1 mutant sușunda, fungus hücre duvarlarından saflaștırılmıș kolloidal kitin içeren uygulamalarda mikoparazitizmi uyarmak için ekzokitinaz nagi veya endokitinaz ech42 geninin ekspresyonuna ihtiyaç duyulduğunu göstermiștir [19]. Farklı Trichoderma türleri, fungusun misellerini enfekte eden selülaz, kitinaz, proteaz, glikozit, $\beta-1,3-$ glukanaz, $\beta$-1,6-glukanaz, $N$-asetil- $\beta$-d-hidrolazlar gibi birçok hücre dıșı enzim üretirler [18]. Trichoderma spp. tarafindan kitinaz, glukanaz ve proteaz gibi litik enzimlerin üretimi ve düzenlenmesi de mikoparazitizm/biyokontrol sürecinde önemli rol oynamaktadır [77].

$\mathrm{Bu}$ enzim proteinlerini kodlayan genlerin, bitkilerde birçok patojen funguslara karşı direnç oluşturdukları bilinmektedir [78,79]. Trichoderma spp.'nin selülaz üretiminde oldukça önemli bir yere sahip oldukları belirtilmiştir [80,81]. Birçok araştırıcı tarafından 1990'lı yıllarda yapılan çalışmalarda, biyokontrol enzimlerin yapılarının çok kompleks olduğu ve bunların çoğunu kodlayan genlerin izole edildiği ve sekans analizlerinin yapıldığı ifade edilmiştir [82,83]. Enzimlerin fungitoksik olduğu ve enzim karışımlarının antifungal özelliklerinin sinerjistik olduğu ve Trichoderma'dan elde edilen farklı kitinolitik veya glukanolitik enzimlerin, farklı organizmalardan gelen enzimler gibi sinerjik olduğu belirtilmektedir [84].

Biyokontrol ajanlarının bitki patojeni funguslara karşı antagonistik etkilerini arttırmak amacıyla farklı enzimler üreten Trichoderma türleri ile birçok çalışma yapıldığı bilinmektedir [85].

\section{Trichoderma spp.'nin bitki gelişimini teşvik etmesi}

Trichoderma spp. bitki gelişimini teşvik edici, verimi arttırıcı etkileri ve aynı zamanda bitki hastalıklarıyla mücadelede biyokontrol ajanı olarak kullanılan çok yönlü işlevleri olan simbiyotik funguslardandır [86]. Trichoderma türleri sadece patojenler için bir biyokontrol ajanı değil, aynı zamanda bitki büyümesi ve kök gelişimini (biyo gübre) arttıran ve bitki savunma mekanizmalarını uyaran antagonistlerdir [18]. Bazı Trichoderma türlerinin epidermise nüfuz ettiği ve kök yüzeylerinde sağlam ve uzun süreli kolonizasyon oluşturduğu ifade edilmekte [18] marul, domates ve biberde bitki gelişimini arttırdığı gözlenmiştir [87]. Yapılan bir çalışmada; Trichoderma harzianum T-22 türü uygulanan mısır bitkilerinde birkaç ay sonra bitki kökleri, kontrol bitkileri ile karşılaştırıldığında yaklaşık iki kat daha uzun olduğu belirtilmiştir [18]. Cutler ve ark. [88,89], Trichoderma koningii (koniningin A) ve Trichoderma harzianum (6-pentyl alpha pryone) türlerinin ürettiği sekonder metabolitlerin bitki büyüme düzenleyicileri olarak görev yaptığı ortaya konulmuştur. Trichoderma uygulanan bitkilerde, sitokinin (Zeatin) ve giberellin benzeri moleküller (GA3 veya GA4) [90], fitohormonlar [18,91,92,93-94] da dahil olmak üzere sekonder metabolitlerin üretimi ile bitki gelişim parametreleri, bitki gelişimi [18,91] ve veriminin [95] artması sayesinde fotosentez oranı [96], besin maddesi alımı, abiyotik ve biyotik strese toleransın artması nedeniyle çeltik ve mısır gibi birçok üründe bitki gelişimi, verim ve ürün miktarı artışı kaydedilmiştir. Trichoderma türleri ayrıca glukonik ve sitrik asit üreterek, toprak pH'ını düşürmekte ve fosfatların, mikro besin maddelerinin, demir, magnezyum ve manganez gibi mineral bileşenlerin çözünürlüğünü arttırmaktadır [9,97-19]. Günümüzde Trichoderma'lar; biyopestisit, 
biyogübre, bitki gelişimi ve verim arttırıcı, ayrıca besin maddesi çözücü ve organik madde ayrıștırıcıları olarak pazarlanmaktadırlar [98]. Trichoderma spp. toprakta fosforu çözerek alınabilir forma getirerek, organik maddeyi ayrıștırmakta ve bitkilerde mikro besin maddelerinin artmasına yardımcı olmaktadırlar $[87,94]$. Trichoderma erinaceum tohum çimlenme oranı, fide gücü, daha yüksek klorofil içeriği, daha fazla besin maddesi birikimi ile Karuna ve Sahabhagidhan çeltik çeșitlerinin gelişimini teşvik ederek ve verim arttışı sağlayarak biyokontrol ajanı ve biyogübre görevi üstlenerek biyotik ve abiyotik stres koșullarında stres yönetimi ile ilișkili olan bazı enzimlerin artışını sağlamıștır [94].

\section{Trichoderma spp.'nin bitkilerde savunma reaksiyonunu uyarması}

Yapılan çalışmalarda Trichoderma ssp.'nin bitkilerde antagonistik mikroorganizmalara karşı kitinaz, glukanaz ve peroksidaz gibi proteinlerin gen ekspresyonunu uyardığı [99, 100-97]ve bitkilere Trichoderma ile ön uygulama yapılmasının hastalıklara karşı direnci artırdığı ifade edilmiştir [18]. Trichoderma spp. fursatçı (opportonistic) istilacı, bitki büyümesini hızlandıran ve bol miktarda spor üreten funguslar olup, hücre çeperini parçalayan enzimlere (örneğin, selülaz, kitinaz ve glukanaz) sahip ve antibiyotik üreten antagonistlerdir [19]. Ayrıca, Trichoderma spp.'nin varlığı, bitkilerde aşırı duyarlılık (HR), sistemik kazanılmış dayanıklılık (SAR) ve uyarılmış sistemik dayanıklılığı (ISR) teşvik etmektedir [9,19;Tablo 2]. Bu konuda yürütülen çalışmalarda, domateste T. hamatum'un bitki fizyolojisinde ve hastalık direncinde aktif olarak sistemik değişikliklere neden olduğu [101], hıyar bitkilerinde ise, T. asperellum'un, fenilalanin ve hidroperoksidaz liyazı kodlayan iki savunma geninin sistemik uyarılmış reaksiyonu ve Pseudomonas syringae pv. lachrymans'a karşı fitoaleksinlerin sistemik olarak birikimini aktive ettiği bildirilmiştir [99]. T. harzianum ve Ganoderma boninense uygulanmış palmiye ağacında kitinaz ekspresyonunun savunma geni, sadece $G$. boninense ile uygulanan bitkilerle karşılaştırıldığında arttığı ifade edilmiştir [102]. Ayrıca yapılan bazı çalışmalarda Trichoderma spp.'nin sistemik dayanıklılığa dolaylı olarak katkıda bulunabileceği belirtilmiştir [103, 104]. Harman ve ark. [18], Trichoderma spp. lokal veya sistemik dayanıklılığı uyarması nedeniyle bitki hastalıklarıyla mücadelede önemli bir faktördür. Dolayısıyla Trichoderma spp.'nin konukçu bitkilerde lokal veya sistemik dayanıklılık reaksiyonlarını teşvik eden belirli bileșikler ürettiği [91,105], bu nedenle Trichoderma ların bitki kök kolonizasyonunun hastalıkla mücadelede etkili olduğu ve söz konusu konukçu bitki, patojen, biyokontrol etmeni ve çeşitli çevresel faktörler arasında karmaşılk bir interaksiyon olduğu ortaya konulmuştur [18,106-101].

Endofitik Trichoderma, bitki gen ekspresyonundaki değişiklik nedeniyle bitki fizyolojisini değiştirmekte, besin maddesi alımını ve hastalıklara karşı direnci arttırmaktadır. Toprağa ve tohuma uygulanan T. asperellum, T. harzianum vb. metabolik değişiklikleri uyararak bitki patojenlerine karşı SAR'ı teşvik etmektedirler [107]. 
Tablo 2. Trichoderma spp.'nin bitkilerde uyarılmış sistemik dayanıklılık (ISR) mekanizması

\begin{tabular}{|c|c|c|}
\hline $\begin{array}{l}\text { Trichoderma spp., Bitki ve } \\
\text { Patojen }\end{array}$ & $\begin{array}{l}\text { Uyarılmış sistemik } \\
\text { dayanıklılık (ISR) }\end{array}$ & Kaynak \\
\hline $\begin{array}{l}\text { T. harzianum (T-39): } \\
\text { Domates, biber, tütün, marul, } \\
\text { fasulye: Botrytis cinerea }\end{array}$ & Yapraklarda hastalık yok & $\begin{array}{l}\text { De Meyer ve ark. } \\
\text { [107] }\end{array}$ \\
\hline Bağ: Plasmopara viticola & $\begin{array}{l}\text { Savunma mekanizmalarının } \\
\text { uyarılması }\end{array}$ & Levy ve ark. [108] \\
\hline $\begin{array}{l}\text { Hıyar, fasulye, domates ve } \\
\text { çilek: B. cinerea; } \\
\text { Podosphaera xanthii }\end{array}$ & $\begin{array}{l}\text { Yaprak hastalıklarından } \\
\text { korunma }\end{array}$ & Levy ve ark. [108] \\
\hline $\begin{array}{l}\text { T. harzianum T-22; } T \text {. } \\
\text { atroviride P1 Fasulye: } B . \\
\text { cinerea, Xanthomonas } \\
\text { campestris pv. phaseoli }\end{array}$ & $\begin{array}{l}\text { Yapraklarda antifungal } \\
\text { bileşiklerle ilişkili yolların } \\
\text { uyarılması }\end{array}$ & Harman ve ark. [97] \\
\hline $\begin{array}{l}\text { T. harzianum T-1 \& T-22; T. } \\
\text { virens } \mathrm{T} 3 \\
\text { Hiyar: Green-mottle, mosaic } \\
\text { virus }\end{array}$ & $\begin{array}{l}\text { Türlerin köke inokulasyonu ile } \\
\text { yaprakların hastalıktan } \\
\text { korunması }\end{array}$ & Lo ve ark. [104] \\
\hline $\begin{array}{l}\text { T. harzianum T-22 Domates: } \\
\text { Alternaria solani }\end{array}$ & $\begin{array}{l}\text { Türlerin köke inokulasyonu ile } \\
\text { yaprakların hastalıktan } \\
\text { korunması }\end{array}$ & Seaman [109] \\
\hline $\begin{array}{l}\text { Trichoderma GT3-2 Hiyar: } \\
\text { Colletottrichum orbiculare, } \\
\text { Pseudomonas syringae pv. } \\
\text { lachrymans }\end{array}$ & $\begin{array}{l}\text { Lignifikasyonla ilgili savunma } \\
\text { genlerinin aktivasyonu }\end{array}$ & Koike ve ark. [110] \\
\hline $\begin{array}{l}\text { T. harzianum Biber: } \\
\text { Phytophthora capsici }\end{array}$ & $\begin{array}{l}\text { Fitoaleksin kapsidiolün artan } \\
\text { üretimi }\end{array}$ & Ahmed ve ark. [103] \\
\hline $\begin{array}{l}\text { T. asperellum (T-203) Hıyar: } \\
\text { Pseudomonas syringae pv. } \\
\text { lachrymans }\end{array}$ & $\begin{array}{l}\text { Jasmonik asit/etilen } \\
\text { sinyalizasyonu ile ilgili } \\
\text { proteinlerin ekspresyonu }\end{array}$ & $\begin{array}{l}\text { Shoresh ve ark. } \\
\text { [111] }\end{array}$ \\
\hline $\begin{array}{l}\text { T. harzianum Tr6, \& } \\
\text { Pseudomonas sp. Ps14 Hiyar: } \\
\text { Fusarium oxysporum f. sp. } \\
\text { radicis }\end{array}$ & $\begin{array}{l}\text { Her iki tür de savunma genleri } \\
\text { aktivasyonu }\end{array}$ & $\begin{array}{l}\text { Alizadeh ve ark. } \\
\text { [112] }\end{array}$ \\
\hline $\begin{array}{l}\text { T. virens \& T. atroviride } \\
\text { Domates: } A \text {. solani, } B . \\
\text { cinerea, ve } P \text {. syringae pv. } \\
\text { tomato (Pst DC } 3000 \text { ) }\end{array}$ & $\begin{array}{l}\text { SAR'ın uyarılması ile ilişkili } \\
\text { olarak salgilanan proteinler Sm1 } \\
\text { ve Epl }\end{array}$ & $\begin{array}{l}\text { Salas-Marina ve ark. } \\
\text { [113] }\end{array}$ \\
\hline $\begin{array}{l}\text { T. virens G-6, G-6-5 ve G-11 } \\
\text { Pamuk: Rhizoctonia solani }\end{array}$ & $\begin{array}{l}\text { Fungitoksik terpenoid } \\
\text { fitoaleksinlerin oluşumu ile } \\
\text { bitkinin korunması }\end{array}$ & Howell ve ark. [114] \\
\hline
\end{tabular}

\section{Trichoderma spp.'nin bitki kök kolonizasyonu}

Trichoderma spp. ile yapılan çalışmalar, fungusun kök kolonizasyonunu, peroksidaz, kitinaz, $\beta-1,3$ glukanaz, fenilalanin ve biyosentetik sinyalizasyonu bașlatan hidroperoksidaz liyaz enzimler ile bitki savunma reaksiyonlarını uyardığı ve düşük moleküler ağırlıklı fitoaleksinlerin birikimini sağladığı belirtilmiştir [114,99-18]. Yedidia 
ve ark. [21] yapılan çalıșmada T. harzianum T-203 ırkının hıyarda bitki kökünü penetre ettiği, epidermis ve dıș kortekste gelișme gösterdiği, bu durumun da peroksidaz ve kitinaz üretimini uyardığı ifade edilmiștir. Bu nedenle, Trichoderma'nın bitki köklerinde kolonize olması ve bitkinin de hastalıklardan korunması bu interaksiyonun simbiyotik bir ilișki olduğunu göstermektedir. Son yıllarda yapılan bazı çalıșmalarda Trichoderma spp.'nin sadece bitkilerin kök yüzeylerinde değil aynı zamanda bitkilerin çeșitli kısımlarında da endofitik olarak geliștikleri belirtilmiștir [56]. Dolayısıyla bu endofitik türlerin bitki gelișimini teșvik ederek, bitkiyi çeșitli biyotik ve abiyotik stres koşullarından koruduğu ortaya konulmuştur [50].

\section{Trichoderma spp.'nin antibiyotik ve sekonder bileşik üretimi}

Trichoderma türleri tarafından üretilen sekonder bileşikler ve antibiyotikler, antagonistik etkileri nedeniyle biyolojik mücadelede önemli bir rol oynamaktadır $[19,115]$. Sivasithamparam ve Ghisalberti [116]Trichoderma türlerinin polipeptidler, pironlar ve terpenler gibi antibakteriyel ve antifungal antibiyotikler dahil olmak üzere bazı sekonder bileşikler ürettiğini bildirmişlerdir. Antibiyotikler ve sekonder metabolitler savunma reaksiyonunda, simbiyosisde, besin maddesi taşınımında, farklılaşmada, spor oluşumunu ve çimlenmeyi uyarma veya engellemede önemli rol oynamaktadır $[117,19]$. Antibiyotikler genellikle patojenlere karşı biyokontrol etkisi ile ilişkilendirilmektedir. $T$. harzianum'un pyrone benzeri antibiyotik üretimi, Ganumannomyces graminis'e karşı biyokontrol etkisi göstermiştir [118]. Peptit antibiyotik paraselsin, Trichoderma spp.'de özdeșleșen ilk sekonder metabolittir [119,120]. Sivasithamparam ve Ghisalberti [116], Trichoderma spp. tarafından üretilen sekonder metabolitlerin; uçucu bileşikler (örn., 6pentil-alfa-pirron), suda çözünür bileşikler (örn. heptelidik asit) ve alfa-aminoizobutirat yönünden zengin, $\mathrm{N}$-asetillenmiş ve $\mathrm{C}$-ucunda bir amino alkol grubuna sahip 12-22 amino asitten oluşan doğrusal oligopeptitler olan peptaibol bileșikleri olmak üzere üç kategoriye ayrılabileceği öne sürülmüștür.

\section{Trichoderma spp.'nin diğer kullanım alanları}

Reese [121] Trichoderma reesei'nin selülaz enzimi ürettiğini tespit etmesinin ardından, fungusun önemli bir selülaz veya enzim üreticisi olmasının yolu açılmıştır. Trichoderma spp. tarafından üretilen selülaz esas olarak malt (maliting), fırınlama (baking) ve etanol üretiminde kullanılmaktadır [122]. İpliksi yapıda selülolitik Trichoderma spp. çok çeşitli selülaz ve hemiselülazlar üretirler. Lignoselülozik biyomas kağıt hamuru, kağıt ve tekstil endüstrilerinde [123], kullanılmasına rağmen asıl etanol gibi biyoyakıtların üretiminde yer almaktadır $[124,125]$. Trichoderma türleri güvenli endüstriyel enzim üretimi için de kullanılmaktadır [126]. Maserating enzimler, meyve suyu üretiminde mayalanma işlemini iyileştirmek ve çiftlik hayvanları ile evcil hayvan besinlerinde yem katkı maddesi olarak yer almaktadır [127]. Yapılan çalıșmalarda Trichoderma'lar ayrıca tohum çimlenmesinde de kullanılmaktadır. T. viride ve T. resei uygulanmış tohumlarda kontrol bitkilerine kıyasla ayçiçeği tohumlarının çimlenmesini önemli ölçüde arttırdığı belirlenmiștir [128]. Yetiştiriciği yapılan birçok üründe bitki gelişimini arttırmak ve hastalıklardan korumak amacıyla bazı Trichoderma türlerinin ticari olarak üretimi yapılmakta olup, bir çok üründe kullanım alanına sahiptir [129, 28]. Günümüzde RootShieldTM, BioTrek 22TM, T22GTM ve T-22HBTM (Bio-works, ABD); SuprevisitTM (Borregaard BioPlant, Danimarka); BinabTM (Bio-Innovation İsveç); TrichopelTM, TrichojetTM, TrichodowelsTM ve TrichosealTM (Agimm, Yeni Zelanda); TriecoTM (Ecosense Labs, Hindistan) ve Tricho-green (Mycology Lab, Malezya) ticari olarak piyasada yer alan formülasyonlardır. Bu preparatların tümü biyo-kontrol ajanı olarak ruhsatlı olmayıp, bitki büyüme düzenleyicisi, bitki gelişimini teşvik edici ve toprak düzenleyicileri olarak da pazarlanmaktadır. 


\section{Trichoderma'ların Biyotik ve Abiyotik Stres Koşullarında Kullanımları}

\section{Biyotik Stres Yönetiminde Trichoderma'lar}

Trichoderma spp. tahıl, baklagiller, yağlı tohumlu bitkiler, meyveler ve sebzeler, ticari ürünler ve diğer ekonomik öneme sahip ürünlerde çökerten (Pythium spp.), gövde kanseri/çürüme (Phytophthora spp.) solgunluk (Fusarium spp.), kök çürüklüğü, öz çürüklüğü (Rhizoctonia spp., Macrophomina phaseolina, Sclerotium spp., Sclerotinia spp., Botrytis spp.), gövde çürüklügü (Aspergillus spp.), yaprak lekeleri (Alternaria spp.) gibi bir çok fungal hastalıkların biyolojik mücadelesinde etkili biyokontrol ajanlarıdırlar [24; Tablo 3].

\section{Abiyotik Stres Yönetiminde Trichoderma'lar}

Trichoderma spp'nin bitkileri kuraklık, tuzluluk, alkalilik, allelopati, oksidatif stresler, ağır metal birikimi gibi abiyotik stres faktörlerine karşı koruma ve rizobakterilere benzer şekilde bitki ve kök büyümesini arttırarak; artan besin alımı ve oksidatif strese karşı uyarılmış koruma gibi etkilerinin olduğu yapılan araştırmalarla ortaya konulmuştur $[151,152]$.

\section{Kuraklık Stresi}

Kuraklık veya su eksikliği, kısa bir süre için bile olsa, çeltik üretiminde verimi azaltan son derece önemli abiyotik stres faktörlerindendir. T. harzianum T-22 ile kök kolonizasyonu, peroksidaz, kitinaz, $\beta$-1,3-glukanazlar, hidro-peroksit liyaz enzimlerinin ve bitkiye stres koşullarında uzun süre dayanıklılık sağlayan lipoksijenaz, fitoaleksin ve fenol bileşiklerinin miktarlarını arttırmaktadır. Süperoksit dismutaz (SOD), askorbat peroksidaz ve katalaz enzimleri (CAT), zararlı reaktif oksijen türleri (ROS), süperoksit $\left(\mathrm{O}_{2}-\right)$ ve hidrojen peroksit $\left(\mathrm{H}_{2} \mathrm{O}_{2}\right)$ düzeylerini ortadan kaldırmak için enzimatik radikal temizleyiciler olarak görev yaparak bitkilerin su eksikliğine yani kuraklık, metil viologen (MV) maruz kalması ve diğer abiyotik streslere direnmesini sağlayan yükseltgenmeindirgenme durumuna yardımcı olmaktadır [95]. T. harzianum Th-56 ( $30 \mathrm{~g} / \mathrm{lt}$ ) ile çeltik (cv. PSD-17) köklerinin daldırılması kök ve sürgün uzunluğu, yaprak alanı indeksi, toplam kuru madde, nisbi nem ve klorofil içeriği ile membran stabilite indeksinin, katalaz ve peroksidaz aktivitesinin arttmasına ve yaprak kıvırcıklığı, uç yanıklığı ve yaprak yanıklığı/yaşlanan yaprak sayısında azalmaya, serbest prolin birikimi ve daha iyi kuraklık toleransına neden olmaktadır. Dolayısıyla Trichoderma uygulaması kuraklık koşullarında bitkiler tarafından üretilen serbest radikaller ve zararlı bileşiklerin uzaklaşırılmasını sağlamakta ve böylece çeltiğin kuraklıktan etkilenmesini önlemektedir [153]. Domateste Trichoderma spp. [91,95]; Kakao'da T. hamatum DIS2196 [50]; ve mısırda T. hazianum [154] ile yapılan çalışmalarda kuraklık stresi ile mücadelede benzer sonuçların elde edildiği yapılan çalışmalar sonucunda ortaya konulmuştur. 
Tablo 3. Bitki hastalıklarıyla mücadelede bazı Trichoderma türleri

\begin{tabular}{|c|c|c|c|}
\hline Bitki ve Patojen & Biokontrol ajanları & Uygulama & Kaynaklar \\
\hline $\begin{array}{l}\text { Çeltik (Oryza sativa) } \\
\text { Magnaporthe oryzae } \\
\text { Rhizoctonia solani } \\
\text { Ustilaginoidea virens }\end{array}$ & $\begin{array}{l}\text { T. harzianum } \\
\text { T. harzianum, T. viride, T. harzianum }\end{array}$ & $\begin{array}{l}\text { Tohum, yaprak } \\
\text { Tohum, Fide } \\
\text { Tohum }\end{array}$ & $\begin{array}{l}\text { Chou ve ark. [130] } \\
\text { Pal ve McSpadden Gardener [131] } \\
\text { Kannahi ve ark. [132] }\end{array}$ \\
\hline $\begin{array}{l}\text { Buğday (Triticum aestivum) } \\
\text { Neovossia indica } \\
\text { Ustilago segatum tritici }\end{array}$ & $\begin{array}{l}\text { T. viride, T. harzianum } \\
\text { T. viride, T. lignorum }\end{array}$ & $\begin{array}{l}\text { Tohum } \\
\text { Tohum\& toprak }\end{array}$ & Aggarwal ve ark. $[133,134]$ \\
\hline $\begin{array}{l}\text { Misir (Zea mays) } \\
\text { Fusarium graminearum } \\
\text { Post-fowering stalk rot complex }\end{array}$ & $\begin{array}{l}\text { T. harzianum } \\
\text { T. harzianum (IARI) }\end{array}$ & $\begin{array}{l}\text { Tohum\& toprak } \\
\text { Tohum }\end{array}$ & Kandasamy ve ark. [135] \\
\hline $\begin{array}{l}\text { Sorgum (Sorghum bicolor) } \\
\text { Gloeocercospora sorghi } \\
\text { Colletotrichum sublineolum }\end{array}$ & $\begin{array}{l}\text { T. harzianum } \\
\text { T. harzianum WKY1 }\end{array}$ & $\begin{array}{l}\text { Yaprak } \\
\text { Tohum, toprak }\end{array}$ & $\begin{array}{l}\text { Purohit ve ark. [136] } \\
\text { Wesam ve ark. [137] }\end{array}$ \\
\hline $\begin{array}{l}\text { Nohut (Cicer arietinum) } \\
\text { F. oxysporum f. sp. ciceris } \\
\text { R. solani } \\
\text { R. bataticola } \\
\text { Sclerotium rolfsii }\end{array}$ & $\begin{array}{l}\text { T. harzianum, T. viride, Trichoderma spp. } \\
\text { T. viride, T. virens; T. harzianum, T. viride }\end{array}$ & $\begin{array}{l}\text { Tohum biyo-kapsül; } \\
\text { biyopriming; biyogübre } \\
\text { Tohum, biyokapsüller } \\
\text { Tohum-biyopriming } \\
\text { Toprak-zenginleștiren biyogübre }\end{array}$ & $\begin{array}{l}\text { Pandey ve ark. [138] } \\
\text { Jaisanive ark. [139] } \\
\text { Dubey ve ark. [140] } \\
\text { Pandey ve ark. [138] } \\
\text { Mukherjee ve ark. [31] }\end{array}$ \\
\hline $\begin{array}{l}\text { Güvercin bezelyesi (Cajanus cajan) } \\
\text { Fusarium udum }\end{array}$ & T. viride, T. harzianum & Tohum, toprağa biyogübre & Ram ve Pandey [141] \\
\hline $\begin{array}{l}\text { Maş fasulyesi (Vigna radiata) } \\
\text { Macrophomina phaseolina } \\
\text { R. solani }\end{array}$ & $\begin{array}{l}\text { Trichoderma spp. } \\
\text { T. viride, T. harzianum, T. virens }\end{array}$ & $\begin{array}{l}\text { Tohum, toprak biyokapsül } \\
\text { Tohum-biyopriming } \\
\text { Toprak- zenginleștiren biyogübre }\end{array}$ & $\begin{array}{l}\text { Meena ve ark. [142] } \\
\text { Pandey ve ark. [138] } \\
\text { Dubey ve Patel [143] }\end{array}$ \\
\hline $\begin{array}{l}\text { Soya fasulyesi (Glycine max) } \\
\text { M. phaseolina } \\
\text { Myrothecium Yaprak Lekesi, Antraknoz } \\
\text { Rhizoctonia }\end{array}$ & T. harzianum, T. viride T. viride & $\begin{array}{l}\text { Tohum biyopriming } \\
\text { Toprak- zenginleştiren biyogübre } \\
\text { Tohum kaplama }\end{array}$ & $\begin{array}{l}\text { Pandey ve Gohel [144] } \\
\text { Falah Kuchlan ve ark. [145] }\end{array}$ \\
\hline $\begin{array}{l}\text { Yerfistığı (Arachis hypogaea) } \\
\text { S. rolfsii } \\
\text { Aspergillus niger } \\
\text { Cercosporidium personatum }\end{array}$ & $\begin{array}{l}\text { T. harzianum } \\
\text { T. viride } \\
\text { T. harzianum }\end{array}$ & $\begin{array}{l}\text { Tohum \& toprak } \\
\text { Tohum \& toprak } \\
\text { Tohum ve yaprak }\end{array}$ & $\begin{array}{l}\text { Rakholiya ve ark. [146] } \\
\text { Hossain ve Hossain [147] }\end{array}$ \\
\hline $\begin{array}{l}\text { Patates (Solanum tuberosum) } \\
\text { R. solani }\end{array}$ & T. virens, T. atroviride & Toprak uygulaması & Hicks ve ark. [148] \\
\hline $\begin{array}{l}\text { Patlıcan (Solanum melongena) } \\
\text { Pythium ahanidermatum }\end{array}$ & T. harzianum & Tohum \& toprak & Nirmalkar ve ark. [149] \\
\hline $\begin{array}{l}\text { Domates (Solanum lycopersicum) } \\
\text { Pythium indicum } \\
\text { Meloidogyne javanica }\end{array}$ & $\begin{array}{l}\text { T. harzianum } \\
\text { T. harzianum }\end{array}$ & $\begin{array}{l}\text { Tohum uygulaması } \\
\text { Toprağa ön uygulama }\end{array}$ & $\begin{array}{l}\text { Nirmalkar ve ark. [149] } \\
\text { Sharon ve ark. [150] }\end{array}$ \\
\hline
\end{tabular}




\section{Tuz Stresi}

Tuz stresi tüm dünyada tarımsal üretimde verimi kısıtlayan en önemli abiyotik stres faktörlerinden biri olup, bitkilerde büyüme ve gelişmeyi olumsuz yönde etkileyerek üründe verim ve kaliteyi etkilemekte hatta bitkilerde ölümlere neden olmaktadır.

Tuz stresine maruz kalan Ochradenus baccatus'un bitki fizyolojisini olumsuz etkilemiş ve tohum çimlenmesi, bitki büyümesi, pigment içeriği, membran stabilite indeksi, bitki dokularında su ve toplam lipid içeriğinde önemli bir düşüşe neden olmuştur. Fenol, diasilgliserol, sterol ester, doymamış yağ asitlerinin, süperoksit dismutaz, katalaz, peroksidaz, askorbat peroksidaz, glutatyon redüktaz enzimatik antioksidanlar, lipid peroksidasyonun sentezini hızlandırarak ve seviyelerini arttırarak; sürgünlerde $\mathrm{Na}^{+}$ve $\mathrm{K}^{+}, \mathrm{Mg}^{2+}$ ve $\mathrm{Ca}^{2+}$ içeriğini önemli ölçüde azalmasına sebep olmuştur. Yapılan çalışmada $T$. hamatum uygulaması sonucunda, yukarıda ifade edilen metabolik süreçler ve tuz stresinin bitki büyümesi üzerindeki zararlı etkisinin azaldığı belirtilmiștir [155]. T. asperellum [156] ve T. asperellum ACCC30536 türlerinden "1-aminosiklopropan 1karboksilat (ACC) deaminaz (ACCD) enzimlerinin belirlenmesi, diğer yararlı mikroorganizmalarda olduğu gibi Populus sp.' nin tuzluluk toleransını artırabilen TaACCD genini ortaya çıkardığı belirtilmiştir [157]. Tuz stresinin ortadan kaldırılması amacıyla $T$. hazianum uygulaması konusunda yapılan bazı çalışmalarda, domates [95]; hardal [158]; mısır ve çeltik [151] ile diğer bitkilerde [152] benzer sonuçların elde edildiği sonuçlar rapor edilmiştir.

\section{Topraklarda Ağır Metal Stresi}

Topraklarda biriken ağır metaller hem çevre kirliliği hem de ekosistemde olumsuz etkilere yol açmakta, atmosferde biriken ağır metaller toprak ve suya karışarak bitkilere ve yine topraktan hayvan ve insanlara geçebilmektedir. Bu durum (ağır metal stresi) bitkisel üretimde bitki fizyolojisini olumsuz yönde etkileyerek verim de azalmalara neden olmaktadır.

Yapılan çalışmalarda soğanda T. asperellum uygulaması $\mathrm{Cu}$ birikiminin azaltılmasına ve soğan yapraklarında bir yerden başka bir yere taşınmasına yardımcı olmuş [159]; $T$. atroviride'nin hardalda kullanıldığı çalışmada ise kadmiyum ve nikelin foto ekstraksiyon etkisini geliştirerek hücresel toksisitesini azalttığı belirtilmiştir [160]. T. harzianum, ağır metallere, tuzluluğa karşı toleransı, $R$. solani ve Pseudomanas syringae'ye karșı dayanıklılığı arttırmaktadır [161].

\section{Aşırı Sıcaklık ve Soğuk Stresi}

Bitkiler, hücresel bileșenlerin zarar görmesine neden olan șiddetli stres koșulları altında birikmiş reaktif oksijeni uzaklaştıramazlar. Bu gibi durumlarda, Trichoderma uygulanan bitkilerde, reaktif oksijen türlerini uzaklaştırma yeteneklerini artırarak stresten korunabilmektedirler. T. harzianum AK 20G Irkı lipid peroksidasyon oranını ve elektrolit sızıntısını azaltarak yaprak su içeriğinin ve prolin birikiminin artmasına yardımcı olmakta böylelikle soğuk stresinin olumsuz etkilerinin azalmasına katkı sağlamaktadır [162]. Yapılan çalışmada benzer şekilde, T. harzianum uygulanmış Arabidopsis bitkilerinde, sıcaklık şoku proteinlerinin üretimi nedeniyle bitkinin sıcaklık stresini tolere ettiği belirtilmiştir [163]. 


\section{Sonuç}

Trichoderma genusu ilk olarak 1930 'da Weindling tarafından biyolojik kontrol ajanı olarak tespit edilmesiyle birlikte günümüze kadar söz konusu konu ile ilgili birçok çalışmada Trichoderma spp.'nin bitki hastalıklarına karşı etkili bir biyolojik kontrol ajanı olduğu ortaya konulmuştur. Trichoderma spp.'nin fitopatojen fungusların mücadelesinde biyolojik kontrol mekanizmaları üzerine yapılan çalışmalarda, hem enzimleri kodlayan birkaç genin izolasyonu yapısal veya düzenleyici proteinler hem de Trichoderma türlerinin konukçuda spesifik tanınmasını sağlayan sinyal bileșenleri gibi mekanizmaların daha iyi anlaşılmasına yol açmıştır. Bu konuda ülkemizde ve dünyada hali hazırda birçok çalışma yapılmış ve yapılmaya da devam etmektedir. Dolayısıyla bu etki mekanizmalarının bilinmesi ile tarımsal üretimde hem hasat öncesi hem de hasat sonrası dönemlerde görülen fungal patojenlerle mücadelede daha etkili Trichoderma türleri tespit edilerek, farklı kombinasyonlarının değerlendirilmesiyle başarılı sonuçlar elde edilebilir. Trichoderma türlerinin konukçu bitki-patojen arasındaki interaksiyonu doğru ve etkili bir şekilde yönetildiğinde biyolojik konrol başarıya ulaşmakta ve ayrıca bitkilerde savunma reaksiyonlarının arttırdığı da bilinmektedir. Dolayısı ile Trichoderma spp.'nin etkili bir biyokontrol ajanı olarak kullanılması kesinlikle sürdürülebilir hastalık yönetiminde etkin kontrol yöntemlerinden biri olarak görülmektedir.

\section{Teșekkür}

Bu çalışma, Deniz BULUT'un Uşak Üniversitesi Lisansüstü Eğitim Enstitüsü, Tarım Bilimleri Anabilim Dalı'nda yürütmüş olduğu yüksek lisans tezinin bir bölümünden hazırlanmıştır.

\section{Çıkar Çatışması Beyanı}

Makale yazarları aralarında herhangi bir çıkar çatışması olmadığını beyan etmektedir.

\section{Kaynaklar}

1. FAO. The future of food and agriculture-trends and challenges. FAO, 2017; Rome, p. 163.

2. Koike ST, Gordon TR. Management of Fusarium wilt of strawberry, Crop Protection, 2015; 1-6.

3. Cawoy H, Wagner B, Fickers B, Ongena M. Bacillus Based Biological Control Plnat Diseases, Pesticides in the Modern World: Pesticides Use and Management. China: InTech Europe; 2011.

4. Naher L, Yusuf UK, Ismail A, Hossain K. Trıchoderma Spp.: A Biocontrol agent for sustainable management of plant diseases, Pak. J. Bot., 2014; 46(4): 1489-1493.

5. Gouvea A, Kuhn OJ, Mazaro SM, May-De Mio LL, Deschamps C, Biasi LA and Fonseca, V de C. Controle de doenças foliares e de flores e qualidade pós-colheita do morangueiro tratado com Saccharomyces cerevisiae. Hort. Bras., 2009; 27(4): 527-533.

6. Noling JW. Nematode management in strawberries. University of Florida publication series no. ENY-031, USA, p. 12, 2016.

7. Abd-Elgawad MMM. Optimizing biological control agents for controlling nematodes of tomato in Egypt. Egypt J. Biol. Pest. Cont., 2020; 30:58.

8. Howell CR. Mechanisms employed by Trichoderma species in the biological control of plant diseases: the history and evolution of current concepts. Plant Dis.,2003; 87:4-10. 
9. Benitez T, Rincon AM, Limon MC, Codon AC. Biocontrol mechanism of Trichoderma strains. International Microbiol., 2004; 7: 249-260.

10. Papavizas GC. Trichodema and Gliocladium: Biology, ecology and potential for biocontrol. Ann. Rev. Phytopathol., 1985; 22: 23-54.

11. Koumoutsi, A, Chen XH, Henne A, Liesegang H, Hitzeroth G, Franhe P, Vater J and Borris R. Structural and functional characterization of gene clusters directing nonribosomal syntheis of bioactive cyclie lipopepetides in Bacillus amyloli quefaciens strain FZB42. J. Bactriol., 2004; 186: 1084-1096.

12. Mavrodi DV, Mavrodi OV, McSpaddenss-Gardener BB, Landa BB, Weller DM, Thomashow LS. Identification of differences in genome content among phIDpositive Pseudomonas fluorescens strains by using PCR based substractive hybridization. Appl. Environ. Microbiol., 2002; 68: 5170-5776.

13. Atehnkeng J, Ojiambo PS, Ikotum T, Sikora RA, Cotty PJ, Bandyopadhyay R. Evaluation of atoxigenic isolates of Aspergillus flavus as potential biocontrol agents for aflatoxin in maize. Food Additives \& Contaminants: Part A., 2008; 25: 1266-1273.

14. Gilardi G, Manker DC, Garibaddi A, Gullino ML. Efficacy of the biocontrol agents Bacillus subtilis and Ampebmyces quisqualis applied in combination with fungicides against powdery mildew of Zucchini. J. Plant Diseases Protect., 2008; 115: 208-213.

15. Ahmed MFA, El-Fiki IAI. Effect of biological control of root rot diseases of strawberry using Trichoderma spp. Middle East Journal of Applied Sciences, 2017; 7(3): 482-492.

16. Aydın MH. Bitki Fungal Hastalıklarıyla Biyolojik Savaşta Trichoderma'lar. Türkiye Tarımsal Araştırmalar Dergisi, 2015; 2:135-148.

17. Chet I. Trichoderma-application, mode of action, and potential as a biocontrol agent of soilborne plant pathogenic fungi. In: Innovative approaches to plant disease control. (Ed.) Chet I. New York: John Wiley and Sons; 1987. pp.147-160.

18. Harman, GE, Howell CR, Viterbo A, Chet I, Lorito M. Trichoderma speciesopportunistic, avirulent plant symbionts. Nature Rev. Microbiol., 2004a; 2: 4356.

19. Vinale F, Sivasithamparam K, Ghisalberti LE, Marra R, Woo LS, Lorito M. Trichoderma-plant-pathogen interactions. Soil. Biol. Biochem., 2008; 40: 1-10.

20. Spadaro D, Gullino ML. Improving the efficacy of biocontrol agents against soilborne pathogens. Crop Protection, 2005;24(7):601-613.

21. Yedidia I, Benhamou N, Chet I. Induction of defence responses in cucumber plants (Cucumis sativus L.) by the biocontrol agent Trichoderma harzianum. Appl. Environ. Microbiol., 1999; 65: 10061-1070.

22. Kredics L, Antal Z, Doczi I, Manczinger L, Kevei F, Nagy E. Clinical importance of the genus Trichoderma. A review. Acta Microbiol. Immunol. Hung., 2003; 50:105-117.

23. Harman, GE. Overview of mechanisms and uses of Trichoderma spp. Phytopathology, 2006; 96: 190-194.

24. Pandey RN, Jaisani P, Yadav DL. Trichoderma spp. in the management of stresses in plants and rural prosperity. Indian Phytopathology, 2021; 74: 453-467.

25. Weindling R. Trichoderma lignorum as a parasite of other soil fungi. Phytopathology, 1932; 22: 837- 845.

26. Wells DH. Trichoderma as a biocontrol agent. In: Biocontrol and plant diseases. (Eds.): Mukerji KG and Garg KL. Florida: CRC press; pp. 73. 1988. 
27. Weindling R. Studies on lethal principle effective in the parasitic action of Trichoderma lignorum on Rhizoctinia solani and other soil fungi. Phytopathol., 1934; 24: 1153-1179.

28. Samuels, GJ. Trichoderma: A review of biology and systematics of the genus. Mycol. Res., 1996; 100: 923-935.

29. Irina D, Christian PK. Species and biodiversity in Trichoderma and Hypocera: from aggregate species to species clusters. J. of Zhejiang Uni. Sci., 2004; 6: 100112.

30. Chaverri P, Gazis R, Samuels GJ. Trichoderma amazonicum, a new endophytic species on Hevea brasiliensis and guianensis from the Amazon basin. Mycologia, 2011; 103:139-151.

31. Mukherjee PK, Horwitz BA, Singh US, Mukherjee M, Schmoll M. Trichoderma in agriculture, industry and medicine: an overview. In: Mukherjee PK, Horwitz BA, Singh US, Mukherjee M, Schmoll M (eds) Trichoderma: biology and applications. Nosworthy: CABI; 2013. pp 1-9.

32. Kubicek CP, Bissett J, Druzhinina I, Kullnig-Gradinger C, Szakacs G. Genetic and metabolic diversity of Trichoderma: a case study on South-East Asian isolates. Fungal Genetics and Biology, 2003; 38(3): 310-319.

33. Christian R, Röhrich WM, Jaklitsch H, Voglmayr A, Iversen CZ, Christian B, Henry M, Meinckel R, Komon-Zelazowska M, Druzhinina I, Christian S, Kubicek P, Berg G. Fungal diversity in the rhizosphere of endemic plant species of Tenerife (Canary Islands): relationship to vegetation zones and environmental factors. ISME J, 2009; 3: 79-92.

34. Migheli Q, Balmas V, Komoñ-Zelazowska M, Scherm B, Fiori S, Caria R, Alexey G, Kopchinskiy A, Kubicek CP, Druzhinina IS. Soils of a Mediterranean hot spot of biodiversity and endemism (Sardinia, Tyrrhenian Islands) are inhabited by panEuropean, invasive species of Hypocrea/Trichoderma. Environ. Microbiol. 2009; 11(1): 35-46.

35. Hatvani L, Antal Z, Manczinger L, Szekeres A, Druzhinina IS, Kubicek CP, Nagy A, Nagy E, Vagvolgyi C, Kredics L. Green mold diseases of Agaricus and Pleurotus spp. are caused by related but phylogenetically diferent Trichoderma species. Phytopathology, 2007; 97: 532-537.

36. Kredics L, García Jimenez L, Naeimi S, Czifra D, Urbán P, Manczinger L, Vágvölgyi C, Hatvani L. A challenge to mushroom growers: the green mould disease of cultivated champignons. Topics in applied microbiology and microbial biotechnology, 2010; 1-2: 295-30.

37. Samuels GJ, Dodd SL, Gams W, Castlebury LA, Petrini O. Trichoderma species associated with the green mold epidemic of commercially grown Agaricus bisporus. Mycologia, 2002; 94(1): 146-170.

38. Kredics L, Kocsubé S, Nagy L, Komon-Zelazowska M, Manczinger L, Sajben E, Nagy A, Vágvölgyi C, Kubicek CP, Druzhinina IS, Hatvani L. Molecular identifcation of Trichoderma species associated with Pleurotus ostreatus and natural substrates of the oyster mushroom. FEMS Microbiol Lett., 2009; 300: 5867.

39. Kredics L, Antal Z, Szekeres A, Manczinger L, Doczi I, Kevei F, Nagy E. Production of extracellular proteases by human pathogenic Trichoderma longibrachiatum strains. Acta Microbiol Immunol Hung, 2004; 51: 283-295.

40. Petrini O. Fungal Endophytes of Tree Leaves. In: Andrews JH, Hirano SS (eds) Microbial ecology of leaves. New York: Springer; 1991. pp 179-197.

41. Gazis R, Chaverri P. Diversity of fungal endophytes in leaves and stems of rubber trees (Hevea brasiliensis) in Tambopata. Peru Fungal Ecol.,2010; 4:94-102. 
42. Patel JS, Kharwar RN, Singh HB, Upadhyay RS, Sarma BK. Trichoderma asperellum (T42) and Pseudomonas fluorescens (OKC)-enhances resistance of pea against Erysiphe pisi through enhanced ROS generation and lignifcations. Front Microbiol.,2017; 8: 306.

43. Cummings NJ, Ambrose A, Braithwaite M, Bissett J, Roslan HA, Abdullah J, Stewart A, Agbayani FV, Steyaert J, Hill RA. Diversity of root-endophytic Trichoderma from Malaysian Borneo. Mycol. Progress, 2016; 15: 50.

44. Ghaffari MR, Ghabooli M, Khatabi B, Hajirezaei MR, Schweizer P, Salekdeh GH. Metabolic and transcriptional response of central metabolism afected by root endophytic fungus Piriformospora indica under salinity in barley. Plant Mol. Biol.,2016; 90: 699-717.

45. Chaverri P, Catlebury LA, Samuels GJ, Geiser MD. Multilocus phylogenetic structure within the Trichoderma harzianum/ Hypocrea lixii complex. Mol. Phylogenet. Evol., 2003; 27: 302-313.

46. El Komy MH, Saleh AA, Eranthodi A, Molan YY. Characterization of novel Trichoderma asperellum isolates to select effective biocontrol agents against tomato fusarium wilt. Plant Pathol. J., 2015; 31(1): 50-60.

47. Leon VC, Raja M, Pandian RTP, Kumar A, Sharma P. Studies on opportunistic endophytism of Trichoderma species in rice (Pusa Basmati-1 (PB1)). Indian J. Exp. Biol., 2017; 56: 121-128.

48. Yuan ZL, Chen YC, Zhang CL, Lin FC, Chen LQ. Trichoderma chlorosporum, a new record of endophytic fungi from Dendrobium nobile in China (in Chinese). Mycosystema, 2008; 27: 608-610.

49. Hanada RE, de Jorge Souza T, Pomella AW, Hebbar KP, Pereira JO, Ismaiel A, Samuels GJ. Trichoderma martiale sp. nov., a new endophyte from sapwood of Theobroma cacao with a potential for biological control. Mycol Res., 2008; 112(Pt 11): 1335-1143.

50. Bae H, Sicher RC, Kim MS, KimSH, Strem MD, MeInice RL, Bailey BA. The beneficial endophyte Trichoderma hamatum isolate DS $219 \mathrm{~b}$ promotes growth and delays the onset of the drought response in Theobroma cacao. Journal of Experimental Botany, 2009; 60: 3279-3295.

51. Rosmana A, Samuels GJ, Ismaiel A, Ibrahim ES, Chaverri P, Herawati Y, Asman A. Trichoderma asperellum: a dominant endophyte species in cacao grown in Sulawesi with potential for controlling vascular streak dieback disease. Trop. Plant Pathol., 2015;40:19-25.

52. Rinu K, Sati P, Pandey A. Trichoderma gamsii (NFCCI 2177): A newly isolated endophytic, psychrotolerant, plant growth promoting, and antagonistic fungal strain. J. Basic Microbiol., 2014; 54: 408-417.

53. Chen JL, Sun SZ, Miao CP, Wu K, Chen YW, Xu LH, Guan HL, Zhao LX. Endophytic Trichoderma gamsii YIM PH30019: a promising biocontrol agent with hyperosmolar, mycoparasitism, and antagonistic activities of induced volatile organic compounds on root-rot pathogenic fungi of Panax notoginseng. J. Ginseng Res., 2016; 40:315-324.

54. Romeralo C, Santamaría O, Pando V, Diez JJ. Fungal endophytes reduce necrosis length produced by Gremmeniella abietina in Pinus halepensis seedlings. Biol. Control, 2015; 80:30-90.

55. Samuels GJ, Dodd SL, Lu BS, Petrini O, Schroer HJ, Druzhinina IS. The Trichoderma koningii aggregate species. Stud. Mycol., 2006; 56: 67-133.

56. Druzhinina IS, Seidl-Seiboth, V, Herrera-Estrella A, Horwitz BA, Kenerley CM, Monte E, Mukherjee PK, Zeilinger S, Grigoriev I, Kubicek CP. Trichoderma-The 
genomics of opportunistic success. Nature Reviews Microbiology, 2011; 9: 749759.

57. Lorito M, Woo SL, Harman GE, Monte E. Translational research on Trichoderma: from omics to the feld. Ann. Rev. Phytopathol., 2010; 48:395-417.

58. Hermosa R, Botella L, Keck E, Jiménez JA, Montero-Barrientos M, Arbona V, Gómez-Cadenas A, Monte E, Nicolás C. The overexpression in Arabidopsis thaliana of a Trichoderma harzianum gene that modulates glucosidase activity, and enhances tolerance to salt and osmotic stresses. .J Plant Physiol.,2011; 168:1295-1302.

59. Pieterse CMJ, Reyes AL, Van der Ent S, Van Wees SCM. Networking by smallmolecule hormones in plant immunity. Nature Chemical Biology, 2009; 5: 308316.

60. Salas-Marina MA, Silva-Flores MA, Uresti-Rivera EE, Castro-Longoria E, HerreraEstrella A, Casas-Flores S. Colonization of Arabidopsis roots by Trichoderma atroviride promotes growth and enhances systemic disease resistance through jasmonic acid/ethylene and salicylic acid pathways. European Journal of Plant Pathology, 2011; 131: 15-26.

61. Tucci M, Ruocco M, De Masi L, De Palma M, Lorito M. The beneficial effect of Trichoderma spp. on tomato is modulated by the plant genotype. Mol Plant Pathol. 2011; 12: 341-354.

62. Sarrocco S, Guidi L, Fambrini S, DegI'Innocenti E, Vannacci G. Competition for cellulose exploitation between Rhizoctonia solani and two Trichoderma isolated in the decomposition of wheat straw. J. Plant Pathol, 2009; 91: 331-338.

63. Hjeljord, LG, Stensvand A, Tronsmo A. Effect of temperature and nutrient stress on the capacity of commercial Trichoderma products to control Botrytis cinerea and Mucor piriformis in greenhouse strawberries. Biolog Control, 2000; 19: 149160.

64. Christian R, Röhrich WM, Jaklitsch H, Voglmayr A, Iversen CZ, Christian B, Henry M, Meinckel R, Komon-Zelazowska M, Druzhinina I, Christian S, Kubicek P, Berg G. Fungal diversity in the rhizosphere of endemic plant species of Tenerife (Canary Islands): relationship to vegetation zones and environmental factors. ISME J, 2009; 3: 79-92.

65. Abbas A, Jiang D, Fu Y. Trichoderma spp. as antagonist of Rhizoctonia solani. J. Plant Pathol. Microbiol., 2017; 8(3): 402-409.

66. Rey M, Delgado-Jarana J, Benítez T. Improved antifungal activity of a mutant of Trichoderma harzianum CECT 2413 which produces more extracellular proteins. Appl. Microbiol. Biotechnol., 2001; 55:604-608.

67. Bull CT, Shetty KG, Subbarao KV. Interactions between Myxobacteria, plant pathogenic fungi, and biocontrol agents. Plant Dis., 2002; 86:889-896.

68. Viterbo A, Ramot O, Chernin L, Chet I. Significance of lytic enzymes from Trichoderma spp. in the biocontrol of fungal plant pathogens. Antonie Van Leeuwenheek, 2002; 81: 549-556.

69. Sivan A, Chet I. Degradation fungal cell walls by lytic enzymes of Trichoderma harzianum J. Gen Microbiol., 1989; 135: 675-682.

70. Elad Y. Mycoparasitism. In: Kohmoto, K, Singh, US, Singh, RP (eds) Pathogenesis and host specifi cities in plant disease: histopathological, biochemical, genetic and molecular basis, eucaryotes. Vol. 2. Pergamon, Oxford, 1995. pp 289307.

71. Cherif M, Benhamou N. Cytochemical aspects of chitin breakdown during the parasitic action of Trichoderma sp. on Fusarium oxysporum f. sp. radicislycopersici. Phytopathology, 1990; 80: 1406-1412. 
72. Soglio FK, Bertagnolli BL, Sinclair JB, Yu GY, Eastburn DM. Production of chitinolytic enzymes and endoglucanase in the soybean rhizosphere in the presence of Trichoderma harzianum and Rhizoctonia solani. Biol. Control, 1998; 12: 111-117.

73. Innocenti G, Roberti R, Montanari M, Zakrisson E. Efficacy of microorganisms antagonistic to Rhizoctonia ceralis and their cell wall degrading enzymatic activities. Mycol. Res., 2003; 107 (4): 421-427.

74. Chet, I, Benhamou N, Harman S. Mycoparasitism and lytic enzymes. In: Trichoderma and Gliocladium Vol. 2. (Eds.): Harman GE and Kubick CP. London: Taylor and Francis; 1998. pp. 153-172.

75. Steyaert JM, Ridgway HJ, Elad Y, Stewart A. Genetic basis of mycoparasitism: A mechanism of biological control by species of Trichoderma. J. Crop. Horticul. Sci., 2003; 31: 281-291.

76. Carsolio, C, Benhamou N, Haran S, Cortes C, Gutierrez A, Chet I, Herrera-Estrella A. Role of the Trichoderma harzianum endochitinase gene, ech42, in mycoparasitism. Appl. Environ. Microbioly., 1999; 65: 929-935.

77. Mukherjee KP, Nautiyal CS, Mukhopadhyay AN. Molecular mechanisms of plant and microbe coexistence. Heidelberg: Springer; 2008.

78. Bolar JP, Norelli JL, Wong KW, Hayes, CK, Harman G, Aldwinckle HS. Expression of endochitinase from Trichoderma harzianum in transgenic apple increases resistance to apple scab and reduces vigor. Phytopathology, 2000; 90: 72-77.

79. Bolar JP, Norelli JL, Harman GE, Brown SK, Aldwinckle HS. Synergistic activity of endochitinase and exochitinase from Trichoderma atroviride (T. harzianum) against the pathogenic fungus (Venturia inaequalis) in transgenic apple plants. Transgenic Res., 2001; 10(6): 533-543.

80. Mandels M. Microbial sources of cellulase. Biotechnol. Bioeng. Sym. 1975; 5:81105.

81. Mandels M, Reese ET. Induction of cellulase in Trichoderma viride as influenced by carbon sources and metals. J. Bacteriol., 1957; 73: 269-278.

82. Benitez T, Delgado-Jarana J, Rincón AM, Rey M, Limón MC. Biofungicides: Trichoderma as a biocontrol agent against phytopathogenic fungi. In: Pandalai SG (ed) Recent research developments in microbiology, Research Signpost, Trivandrum, 1998, 2: 129-150.

83. Lorito M, Woo SL, Garcia-Fernandez I, Colucci G, Harman GE, Pintor-Toro JA, Filippone E, Muccifora S, Lawrence CB, Zoina A, Tuzun S, Scala F. Genes from mycoparasitic fungi as a source for improving plant resistance to fungal pathogens. Proc Natl Acad Sci USA, 1998; 95: 7860-7865.

84. Lorito M, Woo SL, Donzelli B, Scala F. Synergistic, antifungal interactions of chitinolytic enzymes from fungi, bacteria and plants. in: Chitin Enzymology II. Muzzarelli RAA. ed. Atec, Grottammare (AP), Italy. P 157-164. 1996.

85. Sood M, Kapoor D, Kumar V, Sheteiwy MS, Ramakrishnan M, Landi M, Araniti Fabrizio, Sharma A. Trichoderma: The "Secrets" of a Multitalented Biocontrol Agent. Plants, 2020; 9: 762.

86. Harman GE. Multifunctional fungal plant symbionts: new tools to enhance plant growth and productivity. New Phytol., 2011; 189(3): 647-649.

87. Vinale F, Marra R, Scale F, Ghisalberti EL, Lorito M, Sivasithamparam K. Major secondary metabolites produced by two commercial Trichoderma strains active different phytopathogens. Letter in Applied Microbiol., 2006; 43: 143-148.

88. Cutler HG, Cox RH, Crumley FG, Cole PD. 6- Pentyl-apyrone from Trichoderma harzianum: Its plant growth inhibitory and antimicrobial properties. Agricul Biolog Chem., 1986; 50: 2943-2945. 
89. Cutler HG, Himmetsbach DS, Arrendale RF, Cole PD, Cox RH. Koninginin A: a novel plant regulator from Trichoderma koningii. Agricul. Biolog. Chem., 1989; 53: 2605-2611.

90. Kashyap PL, Kumar S, Srivastava AK. Nanodiagnostics for plant pathogens. Environ. Chem. Lett., 2017; 15: 7-13.

91. Shoresh M, Mastouri F and Harman GH. Induced systemic resistance and plant responses to fungal biocontrol agents. Annu.Rev. Phytopathol., 2010; 48:21-43

92. Chowdappa P, Mohan Kumar SP, Jyothi Lakshmi M, Upreti KK. Growth stimulation and induction of systemic resistance in tomato against early and late blight by Bacillus subtilis OTPB1 or Trichoderma harzianum OTPB3. Biol. Control, 2013; 65(1): 109-11.

93. Zhao L, Liu Q, Zhang Y, Cui Q, Liang Y. Effect of acid phosphatase produced by Trichoderma asperellum Q1 on growth of Arabidopsis under salt stress. J. Integr. Agric.,2017; 16, 1341-1346.

94. Swain H, Adak T, Mukherjee AK, Mukherjee PK, Bhattacharyya P, Behera S. Novel Trichoderma strains isolated from tree barks as potential biocontrol agents and biofertilizers for direct seeded rice. Microbiol. Res.,2018; 214: 83-90.

95. Mastouri F, Thomas B, Harman GE. Trichoderma harzianum enhances antioxidant defense of tomato seedlings and resistance to water defcit. Mol Plant Microbe Interact., 2012; 25(9): 1264-1271.

96. Doni F, Al-Shorgani NKN, Tibin EMM, Abuelhassan NN, Anizan I, Che-Radziah CMZ. Microbial involvement in growth of paddy. Curr Res J Biol Sci, 2013; 5(6): 285-290.

97. Harman, GE, Petzoldt R, Comis A, Chen J. Interactions between Trichoderma harzianum strain T22 and maize inbred line M017 and effects of these interactions on diseases by Pythium ultimum and Collectotrichum graminicola. Phytopathol., 2004b; 94: 147-153.

98. Woo Sheridan L, Ruocco M, Vinale F, Nigro M, Marra R, Lombardi N, Pascale A, Lanzuise S, Manganiello G, Lorito M. Trichoderma-based products and their widespread use in agriculture. Open Mycol. J. 2014; 8 (Suppl-1, M 4): 71-126.

99. Yedidia I, Shoresh M, Kerem Z, Benhamou N, Kapulnik Y, Chet I. Concomitant induction of systemic resistance to Pseudomonas syringae pv. lachrymans in cucumber by Trichoderma asperellum (T-203) and accumulation of phytoalexins. Appl. Environ. Microbiol., 2003; 69: 7343-7353.

100. Hanson LE, Howell CR. Elicitors of plant defence responses from biocontrol strains of Trichoderma virens. Phytopathol., 2004; 94: 171-176.

101. Alfano G, Lewis Ivey LM, Cakir C, Bos JIB, Miller SA, Madden Kamoun VL, Hoitink JAH. Systemic modulation of gene S. expression in tomato by Trichoderma hamatum 382. Biolog Control, 2007; 97: 429-437.

102. Naher L, Ho CL, Tan SG, Yusuf UK, Abdullah F. Cloning transcripts encoding chitinases from Elaeis guineensis Jacq. and their expression profiles in response to fungal infections. Physiol. Mol. Plant Pathol., 2011; 76: 96-103.

103. Ahmed AS, Sanchez CP, Candela ME. Evaluation of induction of systemic resistance in pepper plants (Capsicum annum) to Phytopthora capsici using Trichoderma harzianum and its relation with capsidiol accumulation. Eur. J. Plant Pathol., 2000; 106: 817-829.

104. Lo, CT, Liao TF, Deng TC. Induction of systemic resistance of cucumber to cucumber green mosaic virus by the root-colonizing Trichoderma spp. Phytopathol., 2000; 90: S47.

105.Bae H, Roberts DP, Lim HS, Strem M, Park SC, Ryu CM. Endophytic Trichoderma isolates from tropical environments delay disease and induce resistance against 
Phytophthora capsici in hot pepper using multiple mechanisms. Mol PlantMicrobe Interact., 2011; 24: 336-351.

106. Hoitink, HAJ, Madden LV, Dorrance AE. Systemic resistance induced by Trichoderma spp.: Interactions between the host, the pathogen, the biocontrol agent, and soil organic matter quality. Phytopathol., 2006; 96: 186-189.

107. De Meyer G, Bigirimana J, Elad Y, Hofte M. Induced systemic resistance in Trichoderma harzianum T39 biocontrol of Botrytis cinerea. Eur. J. Plant Pathol., 1998; 104: 279-286.

108. Levy NO, Meller HY, Haile ZM, Elad Y, David E, Jurkevitch E, Katan J. Induced resistance to foliar diseases by soil solarization and Trichoderma harzianum. Plant Pathol., 2015; 64: 365-374.

109. Seaman A. Efcacy of OMRI-approved products for tomato foliar disease control. N Y State Integr Pest Manag Program Publ.,2003; 129: 164-167.

110. Koike N, Hyakumachi M, Kageyama K, Tsuyumu S, Doke N. Induction of systemic resistance in cucumber against several diseases by plant growth-promoting fungi: lignifcation and superoxide generation. Eur. J. Plant Pathol. 2001; 107: 523-533.

111. Shoresh M, Yedidia I, Chet I. Involvement of jasmonic acid/ ethylene signaling pathway in the systemic resistance induced in cucumber by Trichoderma asperellum T203. Phytopathology, 2005; 95: 76-84.

112. Alizadeh H, Behboudi K, Ahmadzadeh M, Javan-Nikkhah M, Zamioudis C, Pieterse CM, Bakker PA. Induced systemic resistance in cucumber and Arabidopsis thaliana by the combination of Trichoderma harzianum Tr6 and Pseudomonas sp. Ps14. Biol. Control, 2013; 65(1): 14-23.

113. Salas-Marina MA, Isordia-Jasso M, Islas-Osuna MA, Delgado-Sánchez P, JiménezBremont JF, Rodríguez-Kessler M, Rosales-Saavedra MT, Herrera-Estrella A, Casas-Flores S. The Epl1 and Sm1 proteins from Trichoderma atroviride and Trichoderma virens diferentially modulate systemic disease resistance against diferent life style pathogens in Solanum lycopersicum. Front. Plant Sci., 2015; 6: 77.

114. Howell CR, Hanson LE, Stipanovic RD, Puckhaber LS. Induction of terpenoid synthesis in cotton roots and control of Rhizoctonia solani by seed treatment with Trichoderma virens. Phytopathol., 2000; 90: 248-252.

115. Ajitha PS, Lakshmedevi N. Effect of volatile and von-volatile compounds from Trichoderma spp. against Colletotrichum capsici incitant of anthracnose on Bell peppers. Nature and Sci., 2010; 8: 265-296.

116.Sivasithamparam K, Ghisalberti EL. Secondary metabolism in Trichoderma and Gliocladium. In: Trichoderma and Gliocladium. (Eds.): Harman GE and Kubicek CP. Taylor and Francis, London, 1998, 1: 139-191.

117.Demain AL and Fang A. The natural functions of secondary metabolites. Advances in Biochemi Engineer Biotechnol., 2000; 69: 1-39.

118.Ghisalberti EL, Narbey MJ, Dewan MM, Sivasithamparam K. Variability among strains of Trichoderma harzianum in their ability to reduce take-all and to produce pyrones. Plant and Soil, 1990; 121: 287-291.

119. Bruckner H, Graf H. Paracelsin, a peptide antibiotic containing alphaaminoisobutyric acid, isolated from Trichoderma reesei Simmons Part A. Experientia., 1983; 139: 528-530.

120.Bruckner H, Graf H, Bokel M. Paracelsin; characterization by NMR spectroscopy and circular dichroism, and hemolytic properties of a peptaibol antibiotic from the cellulolytically active mold Trichoderma reesei Part B. Experientia., 1984; 40: 1189-1197. 
121. Reese ET. History of the cellulose program at the U.S. Army Natick development center. Biotechnol. Bioeng Sympos., 1976; 6: 9-20.

122.Galante YM, Conti A and Monteverdi R. Application of Trichoderma enzymes in the food and food inductries. In: Trichoderma and Gliocladium, (Eds.): Harman GE and Kubicek CP. Vol. 2. Taylor and Francis, London, 1998b. pp. 327-342.

123.Galante YM, Conti A and Monteverdi R. Application of Trichoderma enzymes in the textile industry. In: Trichoderma and Gliocladium, (Eds.): Harman GE and Kubicek CP. Vol. 2. Taylor and Francis, London, 1998a. pp. 311-326.

124.Lin Y and Tanaka S. Ethanol fermentation from biomass resources: current state and prospect. Appl. Microbiol. Biotechnol., 2006; 69: 627-624.

125.Gimbert HS, Margeor A, Dolla A, Jan G, Molle D, Lignon S, Mathis H, Sigoillot CJ, Monot $\mathrm{F}$ and Asther M. Comparative secretoma analyses of two Trichoderma reesei RUT-C30 and CL847 hypersecretory strains. Biotechnol for Biofuels., 2008; 1 : 18.

126. Nevalaines H, Suominen P, Taimisto K. On the safety of Trichoderma reesei. J. Biotech., 1994; 37: 193-200.

127.Schaster A, Schmoll M. Biology and Biotechnology of Trichoderma. Appl. Microbiol. Biotechnol., 2010; 87: 787-799.

128.Anis M, Zaki MJ, Dawar S. Development of a Naalginate based bioformulation and its use in the management of charcoal rot sunflower (Helianthus annuus L.). Pak. J. Bot., 2012; 44: 1167-1170.

129.Lumsden, RD, Lewis, JA, Lock JC. Managing soilborne plant pathogens with fungal antagonists. In: In pest management: Biology based technologies. American Chemical Society Publishers, Washington, 1993; pp. 196-203.

130.Chou C, Castilla N, Hadi B, Tanaka T, Chib S, Sato I. Rice blast management in Cambodian rice felds using Trichoderma harzianum and a resistant variety. Crop Protect.,2020; 135: 104864.

131.Pal KK, Gardener BMS. Biological control of plant pathogens. The Plant Health Instructor, 2006; pp 1-25.

132. Kannahi M, Dhivya S, Senthil Kumar R. Biological control on rice false smut disease using Trichoderma species. Int. J. Pure. App. Biosci., 2016; 4(2): 311-316.

133. Aggarwal R, Srivastava KD, Singh DV, Bahadur P, Nagarajan S. Possible biocontrol of loose smut of wheat. J. Bio. Control, 1991; 6: 114-115.

134.Aggarwal R, Singh DV, Srivastava KD, Bahadur P. The potential of antagonists for biocontrol of Neovossia indica causing Karnal bunt of wheat. Indian J. Biol. Control, 1996; 9: 69-70.

135.Saravanakumar K, Li Y, Yu C, Wang Q, Wang M, Sun J, Gao J, Chen J. Effect of Trichoderma harzianum on maize rhizosphere microbiome and biocontrol of Fusarium Stalk rot. Sci Rep., 2017; 7: 1771.

136.Purohit J, Singh Y, Bisht S, Srinivasaraghvan A. Evaluation of antagonistic potential of Trichoderma harzianum and Pseudomonas fuorescens isolates against Gloeocercospora sorghi causing zonate leaf spot of sorghum. Bioscan, 2013; 8(4): 1327-1330.

137.Saber WI, Ghoneem KM, Rashad YM, Al-Askar AA. Trichoderma harzianum WKY1: an indole acetic acid producer for growth improvement and anthracnose disease control in sorghum. Biocontrol Sci. Tech.,2017; 27(5): 654-676.

138.Pandey RN, Gohel NM, Jaisani P. Management of wilt and root rot of chickpea caused by Fusarium oxysporum f. sp. ciceri and Macrophomina phaseolina through seed biopriming and soil application of bio-Agents. Int. J. Curr. Microbiol. Appl. Sci., 2017; 6(5): 2516-2522. 
139.Jaisani P, Prajapati HN, Yadav DL, Pandey RN. Seed biopriming and Trichoderma enriched FYM based soil application in management of chickpea (Cicer arietinum L.) wilt complex. J Pure Appl Microbiol., 2016; 10(3): 2453-2460.

140.Dubey SC, Tripathi A, Singh B. Combination of soil application and seed treatment formulations of Trichoderma species for integrated management of wet root rot caused by Rhizoctonia solani in chickpea (Cicer arietinum). Indian J Agric Sci.,2012; 82(4): 357-364.

141.Ram H, Pandey RN. Efficacy of bio-control agents and fungicides in the management of wilt of pigeon pea. Indian Phytopath., 2011; 64(3): 269-271.

142. Meena BN, Pandey RN, Dama R. Seed bio-priming for management of root rot and blight of mungbean incited by Macrophomina phaseolina (Tassi) goid. and Rhizoctonia solani Kuhn. J. Pure Appl. Microbiol., 2016; 10(2): 1223-1510.

143.Dubey SC, Patel B. Mass multiplication of antagonists and standardization of efective dose for management of web blight of urd and mung bean. Indian Phytopath., 2002; 55: 338-341.

144.Pandey RN, Gohel NM, Jaisani P. Management of wilt and root rot of chickpea caused by Fusarium oxysporum f. sp. ciceri and Macrophomina phaseolina through seed biopriming and soil application of bio-Agents. Int. J. Curr. Microbiol. Appl. Sci., 2017; 6(5): 2516-2522.

145.Falah Kuchlan PMMM, Ansari K, Kuchlan MM, Ansari MM. Effcient application of Trichoderma viride on soybean [Glycine max (L.) Merrill] seed using thin layer polymer coating. Legume Res.,2019; 42(2): 60-64.

146. Rakholiya KB, Jadeja KB. Efect of seed treatment of biocontrol agents and chemicals for the management of stem and pod rot of groundnut. Int. J. Plant Prot.,2010; 3(2): 276-278.

147. Hossain $\mathrm{MH}$, Hossain I. Evaluation of three botanicals, bavistin and BAUbiofungicide for controlling Leaf spot of groundnut caused by Cercospora arachidicola and Cercosporidium personatum. Agriculturists, 2014; 12(1): 41-49.

148. Hicks E, Bienkowski D, Braithwaite M, Kirstin M, Richard Falloon R, Stewart A. Trichoderma strains suppress Rhizoctonia diseases and promote growth of potato. Phytopathologia Mediterranea, 2014; 53(3): 502-514.

149. Nirmalkar VK, Tiwari RKS, Singh S. Efficacy of bio-agents against damping of in solanaceous crops under nursery conditions. Int. J. Plant Protect., 2018; 11(1): 1-9.

150.Sharon E, Bar-Eyal M, Chet I, Herrera-Estrella A, Kleifeld O, Spiegel Y. Biological control of the root-knot nematode Meloidogyne javanica by Trichoderma harzianum. Phytopathology, 2001; 91: 687-693.

151.Yasmeen R, Siddiqui ZS. Physiological responses of crop plants against Trichoderma harzianum in saline environment. Acta Bot. Croat, 2017; 76(2): 154-162.

152.Hidangmayum A, Dwivedi P. Plant responses to Trichoderma spp. and their tolerance to abiotic stresses: a review. J Pharmacogn Phytochem., 2018;7(1): 758-766.

153.Pandey V, Ansari MW, Tula S, Yadav, Sahoo RK, Shukla N, Bains G. Dosedependent response of Trichoderma harzianum in improving drought tolerance in rice genotypes. Planta, 2016; 243: 1251-1264.

154.Harman GE. Myths and dogmas of biocontrol. Changes in perceptions derived from research on Trichoderma harzianum T-22. Plant Dis., 2000; 84: 377-393.

155.Hashem Abeer EF, Abd_Allah AA, Alqarawi AA, Al Huqail AA, Egamberdieva D. Alleviation of abiotic salt stress in Ochradenus baccatus (Del.) by Trichoderma hamatum (Bonord.) Bainier. J. Plant Interact., 2014; 9(1): 857-868. 
156.Viterbo A, Landau U, Kim S, Chernin L, Chet I. Characterization of ACC deaminase from the biocontrol and plant growth promoting agent Trichoderma asperellum T203. FEMS Microbiol. Lett., 2010; 305: 42-48.

157.Zhang M, Liu JM, Zhao JL, Li N, Chen RD, Xie KB, Zhang WJ, Feng KP, Yan Z, Wang N, Dai JG. Two new diterpenoids from the endophytic fungus Trichoderma sp. Xy24 isolated from mangrove plant Xylocarpus granatum. Chinese Chemical Letters, 2016; 27(6): 957-960.

158.Ahmad P, Abeer H, Elsayed FAA, Alqarawi AA, Rifat J, Dilfuza E. Role of Trichoderma harzianum in mitigating $\mathrm{NaCl}$ stress in Indian mustard (Brassica juncea L.) through antioxidative defense system. Front Plant Sci., 2015; 6: 868.

159.Tellez-Vargas J, Rodríguez-Monroy M, López-Meyer M, Montes-Belmont R, Sepúlveda-Jiménez G. Trichoderma asperellum ameliorates phytotoxic efects of copper in onion (Allium cepa L.). Environ. Exp. Bot., 2017; 136: 85-93.

160.Cao L, Jiang M, Zeng Z, Du A, Tan H, Liu Y. Trichoderma atroviride F6 improves phytoextraction efciency of mustard (Brassica juncea (L.) Coss.var. foliosa Bailey) in Cd, Ni contaminated soils. Chemosphere, 2008; 71(9): 1769-1773.

161.Dana MM, Pintor-Toro JA, Cubero B. Transgenic tobacco plants overexpressing chitinases of fungal origin show enhanced resistance to biotic and abiotic stress agents. Plant Physiol., 2006; 142: 722-730.

162.Ghorbanpour A, Salimi A, Ghanbary MAT, Pirdashti H, Dehestani A. The efect of Trichoderma harzianum in mitigating low temperature stress in tomato (Solanum lycopersicum L.) plants. Sci Hortic., 2018; 230: 134-141.

163. Montero-Barrientos M, Hermosa R, Cardoza, RE, Gutierrez S, Nicolás C, Monte E. Transgenic expression of the Trichoderma harzianum HSP70 gene increases Arabidopsis resistance to heat and other abiotic stresses. J. Plant Physiol., 2010; 167: 659-665. 